III. Third Party Actions

\title{
THIRD-PARTY ACTION OVER AGAINST WORKERS' COMPENSATION EMPLOYER
}

\author{
ARTHUR LARSON*
}

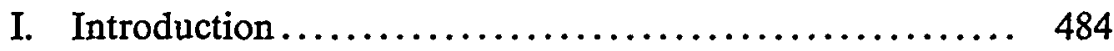

II. Contribution: Majority Rule Banning............. 488

III. Limited Contribution: Minority Rule Permitting....... 489

A. Early Federal Cases.......................... 489

B. The Former "Pennsylvania Rule"................ 491

C. The Minnesota Rule in Lambertson .............. 492

D. The California and North Carolina Approach ....... 493

E. The "Murray Credit" Rule ...................... 494

F. The New York Rule in Dole ................. 497

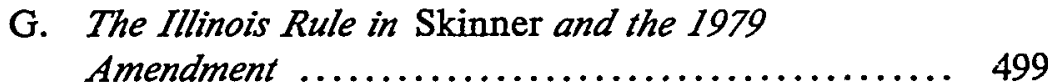

IV. Indemnity: Express Contract.................... 500

A. Normal Rule: Express Indemnity Not Barred ....... 500

B. The Minority Alabama Rule ................... 501

C. Specific Statutory Treatment of Express Indemnity... 503

D. Employer Not Joinable as Indemnitor ............. 504

E. Indemnity Agreement Not a Third-Party Defense .... 505

V. Indemnity Growing out of Separate Duty Based on Relationship.............................. 505

VI. Implied Contractual Indemnity................. 508

A. Implied Contractual Indemnity under the
Longshoremen's Act ..................... 508

1. Summary of the Longshoremen's Act Story ...... 508

2. Pre-1972 Federal Law .................... 510

* James B. Duke Professor of Law Emeritus, Duke University School of Law.

Copyright (C) 1982 West Virginia Law Review. Reprinted by permission from W. Vir. L. Rev. 893 (1982). 
(a) The Ryan Doctrine ................... 510

(b) The "service aspect" of the Ryan Doctrine .. 511

(c) Scope of the Ryan Doctrine ............. 513

3. Developments since the 1972 Longshoremen's Act Amendments ............................. 516

(a) Attempts to evade the recovery-over restriction ............................. 516

(b) Attempts to broaden the grounds for liability of the ship ............................ 520

(c) Effect of the 1972 Amendments on nonvessel third parties ......................... 522

(d) Effect of 1972 Amendments on FECA liabilities.............................. 524

B. Implied Contractual Indemnity under State Law ..... 525

VII. Noncontractual Indemnity...................... 528

A. Summary of Case Law..................... 528

B. Relation between Noncontractual Indemnity,

Contractual Indemnity, and Contribution .......... 530

VIII. Policy Arguments and Merits of Various Solutions...... 534

A. Solutions Arrayed by Interests Affected ........... 535

B. Solutions Arrayed by Values Served .............. 538

C. Suggested Solution Maximizing Simplicity ......... 540

\section{INTRODUCTION}

Perhaps the most evenly-balanced controversy in all of workers' compensation law is the question whether a third party in an action by the employee can get contribution or indemnity from the employer, when the employer's negligence has caused or contributed to the employee's injury. ${ }^{1}$ The typical fact situation is that in American District Telegraph Co. v. Kittleson. ${ }^{2}$ Kittleson was an employee of Armour \&

1. This sentence, first published in 1953 and found now in A. LARSON, WORKMEN'S COMPENSATION $\$ 76.10$ (1982), has been quoted frequently as a preamble to opinions or articles on this question. See, e.g., General Elec. Co. v. Cuban Am. Nickel Co., 396 F.2d 89, 90 (5th Cir. 1968); Newport Air Park, Inc. v. United States, 293 F. Supp. 809, 816 n.17 (D.R.I. 1968); McDonnell Aircraft Corp. v. Hartman-Hanks-Walsh Painting Co., 323 S.W.2d 788, 794 (Mo. 1959); Comment, 22 N.A.C.C.A. L.J. 235, 236-37 (1958). The statement is as true now as it ever was.

2. 179 F.2d 946 (8th Cir. 1950), rev'g 81 F. Supp. 25 (N.D. Iowa 1948). The decisional history of this case is itself representative of the zigzag course the issue has taken over the past three decades. The federal district court, applying Iowa law, dismissed American's complaint; the Court of Appeals for the Eighth Circuit, also applying Iowa law, reversed. Later, in Iowa Power \& Light Co. v. Abild Constr. Co., 259 Iowa 314, 324, 144 N.W. 2d 303, 309 (1966), the state supreme court held that the Eighth Circuit had been mistaken about Iowa law. Finally, on the strength of Abild, in Hysell v. Iowa Pub. Serv. Co., 534 F.2d 775 (8th Cir. 1976), the Eighth Circuit repudiated its own Kittleson decision. Id. at 782-83. 
Company. American District Telegraph had contracted with Armour to repair a signal system. One of American's employees fell through a skylight and landed on Kittleson, injuring him severely. Kittleson accepted workers' compensation from Armour, and also sued American, as he was entitled to do under the Iowa Act. ${ }^{3}$ The negligence alleged was that of American's employee in failing to ascertain whether the skylight could support his weight. American brought a third-party complaint against Armour, asserting that the injury was primarily due to Armour's negligence in allowing the skylight to become so encrusted with dirt that it was indistinguishable from the roof around it. Armour moved to dismiss the third-party complaint on the ground that Armour's compensation liability was exclusive. It is interesting to note that the compensation liability amounted to $\$ 6,800$, while the judgment recovered against American was almost $\$ 60,000$. The district court dismissed the third-party complaint. The circuit court of appeals reversed, and held that Armour could be held liable to American for the damages that American had to pay Armour's employee. ${ }^{4}$

Each side to this controversy has an argument in its favor which, considered alone, sounds irresistible. The employer here complains with considerable cogency that the net result is that $\$ 60,000$ has been put in the employee's pocket and has left the employer's pocket because of a compensable injury, in spite of the plain statement in the act that the employer's liability for such an injury shall be limited to compensation payments. 5 Yet if the third party were made to bear the entire $\$ 60,000$ damages, he would argue with equal cogency that it is unfair to subject him, the lesser of two wrongdoers, to a staggering liability which he would not have had to bear but for the sheer chance that the other parties involved happened to be under a compensation act. Why should he, a stranger to the compensation system, subsidize that system by assuming liabilities that he could normally shift to or share with the employer?

Because of the closeness of the issue, the number and variety of attempted solutions, both legislative and judicial, has been nothing short of breathtaking, and the end is by no means in sight. Even when deliberate legislative choices have been made, that has not necessarily been the end of the matter, for more than once the courts have had the last word by declaring statutes unconstitutional. ${ }^{6}$ Indeed, few areas of

3. Kittleson v. American Dist. Tel. Co., 81 F.Supp. 25, 31 (N.D. Iowa 1948), rev'd, 179 F.2d 946 (8th Cir. 1950); see IowA CoDE ANN. $\$ 85.22$ (West 1976).

4. 179 F.2d at 954-55.

5. See IOWA CODE ANN. \& 85.22 (West 1976).

6. E.g., Ocean Accident \& Guar. Corp. v. Poulsen, 244 Wis. 286, 12 N.W.2d 129 (1943). 
law have evoked such daring displays of uninhibited judicial activism, with centuries-old doctrines being bulldozed out of the way to clear a path for an "equitable" compromise.

At the time Kittleson was decided, in 1950, while the third-party problem was a major one in the intellectual sense, it did not loom very large in the quantitative sense. The reason was that the state of the law governing the injured employee's possible third-party tort rights had not developed anything resembling the opportunities that began to appear a few years later. The employee's case would ordinarily involve plain negligence by the third party directly contributing to a collision or other typical industrial accident. But, after all, workers are not injured every day by the falling bodies of telephone repairmen. And so, while the legal controversy was no less exasperating then than now, the sheer volume of hardship created was not yet sufficient to touch off the explosion of remedial efforts that came later.

Two principal developments, each vastly increasing the injured worker's possible third-party recoveries, and thus equally increasing the potential for inequity as between third party and employer, account for the prominence of this problem in the last twenty-five years; first, the extension of the unseaworthiness doctrine to longshoremen, and then the upsurge of products liability litigation.

In Seas Shipping Co. v. Sieracki, ${ }^{7}$ the Supreme Court held that the virtual nonfault liability of the ship for unseaworthiness extended to longshoremen. This holding laid the groundwork for Ryan Stevedoring Co. v. Pan-Atlantic Steamship Corp. ${ }^{8}$ which dominated this area for about fifteen years. Here the Supreme Court held that a contract to perform stevedoring operations implied an agreement with the shipowner to perform these services in a workmanlike way, and a further agreement to indemnify the shipowner for any liabilities he might incur as a result of failure to live up to this promise. ${ }^{9}$ Moreover, this duty, being contractual in nature, was not affected by the exclusive remedy clause of the compensation act. ${ }^{10}$ The advent of the Ryan doctrine coincided with a vast expansion of the doctrine of unseaworthiness, extending it, for example, to conditions on dry land." Indeed, at the time of Ryan, the Supreme Court itself had expanded the concept to include assault by a fellow worker. ${ }^{12}$ Since the net result of all this was, in
7. 328 U.S. 85 (1946).
8. 350 U.S 124 (1956).
9. Id. at 133-34.
10. Id. at 132.
11. See, e.g., Thompson v. Calmar S.S. Corp., 331 F.2d 657 (3d Cir. 1964).
12. Boudoin v. Lykes Bros. S.S. Co., 348 U.S. 336 (1955). 
effect, to shift the full burden of the ship's damage liability to the stevedoring employer, there was mounting complaint that the employer's supposed immunity to damage liability had been destroyed. The result was the Congressional abolition in 1972 of both the Sieracki and the Ryan doctrines, in exchange for a dramatic liberalization of the Longshoremen's Act (LHWCA). ${ }^{13}$ But if this was intended to put an end to controversy in the field, it was far from successful, with the appearance of multifarious efforts to revive third-party actions against the shipowner under some rubric other than unseaworthiness, such as actual negligence, occupier's liability, and assorted other doctrines. ${ }^{14}$

The second-and vigorously continuing-development contributing to the proliferation of litigation in this field is the expansion of products liability. Defective machine tools, cranes and scaffolding, dangerous chemicals, and the like have produced many more thirdparty damage awards to employees than were dreamed of twenty years earlier. This development, in turn, has understandably placed severe pressure on the classical compensation doctrine that the employer, having been relieved of all tort liability to his own employee by the exclusive-remedy clause of the compensation act, cannot be liable to the third party either for contribution ${ }^{15}$ or for noncontractual indemnity. ${ }^{16}$

This article surveys the current state of the law on third-party attempts at recovery-over against the employer. It discusses the various solutions developed in the courts and legislature, and finally suggests possible compromise to resolve the issue. The cases can best be sorted out by identifying three possible situations:

The third party seeks a tort-type recovery-over against the employer (contribution).

The third party seeks a contract-type recovery-over against the employer (express or implied indemnity); the source of the employer's relation to the third party is contractual.

The third party seeks a contract-type recovery-over against the employer (implied indemnity); the relation between the third party and the employer is not contractual in origin.

13. Longshoremen's and Harbor Workers' Compensation Act $\S 5$ (b), 33 U.S.C. § 905(b) (1976), as amended by Longshoremen's and Harbor Workers' Compensation Act Amendments of 1972, Pub. L. No. 92-576, § 18(a), 86 Stat. 1263 [hereinafter referred to as the 1972 Amendments].

14. See notes 184-253 infra and accompanying text.

15. See notes 17-19 infra and accompanying text.

16. See note 267 infra and accompanying text. 


\section{Contribution: Majority Rule Banning}

The great majority of jurisdictions have held that the employer whose concurring negligence contributed to the employee's injury cannot be sued or joined by the third party as a joint tortfeasor, whether under contribution statutes or at common law. ${ }^{17}$ The ground is a simple one: the employer is not jointly liable ${ }^{18}$ to the employee in tort; therefore he cannot be a joint tortfeasor..$^{19^{\circ}}$ The liability that rests upon the employer is an absolute liability irrespective of negligence, and this is the only kind of liability that can devolve him upon whether he is negligent or not. The claim of the employee against the employer is solely for statutory benefits; his claim against the third person is for damages. The two are different in kind and cannot result in a common liability.

17. Pope \& Talbot, Inc. v. Hawn, 346 U.S. 406 (1953); Halcyon Lines v. Haenn Ship Ceiling \& Refitting Corp., 342 U.S. 282 (1952); Dawn v. Essex Conveyors, Inc., 498 F.2d 921 (6th Cir.), cert. denied, 419 U.S. 1040 (1974) (applying Tennessee law); Newport Air Park, Inc. v. United States, 419 F.2d 342 (1st Cir. 1969); Murray v. United States, 405 F.2d 1361 (D.C. Cir. 1968) (applying the Federal Employees' Compensation Act); Maddux v. Cox, 382 F.2d 119 (8th Cir. 1967); Ocean Drilling \& Exploration Co. v. Berry Bros. Oilfield Serv., 377 F.2d 511 (5th Cir. 1967); Bertone v. Turco Prods., Inc., 252 F.2d 726 (3d Cir. 1958); Hill Lines, Inc. v. Pittsburgh Plate Glass Co., 222 F.2d 854 (10th Cir. 1955); American Mut. Liab. Ins. Co. v. Matthews, 182 F.2d 322 (2d Cir. 1950); Harn v. Standard Eng'g Co., 416 F.Supp. 1168 (D.S.D. 1976) (applying South Dakota law); Redwing Carriers, Inc. v. Crown Cent. Petroleum Corp., 356 So. 2d 1203 (Ala. 1978); Arctic Structures, Inc. v. Wedmore, 605 P.2d 426 (Alaska 1979); Jack Morgan Constr. Co. v. Larkan, 254 Ark. 838, 496 S.W.2d 431 (1973); Powell v. Interstate Vendaway, Inc., 300 A.2d 241 (Del. 1972); Kamali v. Hawaiian Elec. Co., 54 Hawaii 153, 504 P.2d 861 (1972); Iowa Power \& Light Co. v. Abild Constr. Co., 259 Iowa 314, 144 N.W. 2d 303 (1966); Houk v. Arrow Drilling Co., 201 Kan. 81, 439 P.2d 146 (1968); Ashland Oil \& Ref. Co. v. Bertram \& Thacker, 453 S.W.2d 591 (Ky. 1970); Roberts v. American Chain \& Cable Co., 259 A.2d 43 (Maine 1969); Baltimore Transit Co. v. State, 183 Md. 674, 39 A.2d 858 (1944); Liberty Mut. Ins. Co. v. Westerlind, 374 Mass. 524, 373 N.E.2d 957 (1978); Husted v. Consumers Power Co., 376 Mich. 41, 135 N.W.2d 370 (1965); Cordier v. Stetson-Ross, Inc., 604 P.2d 86 (Mont. 1979); Vangreen v. Interstate Mach. \& Supply Co., 197 Neb. 29, 246 N.W.2d 652 (1976); William H. Field Co. v. Nuroco Woodwork, Inc., 115 N.H. 632, 348 A.2d 716 (1975); Schweizer v. Elox Div. of Colt Indus., 70 N.J. 280, 359 A.2d 857 (1976); Beal v. Southern Union Gas Co., 62 N.M. 38, 304 P.2d 566 (1956): Hunsucker v. High Point Bending \& Chair Co., 237 N.C. 559, 75 S.E.2d 768 (1953); Essick v. City of Lexington, 232 N.C. 200,60 S.E.2d 106 (1950); Gernand v. Ost Serv. Inc., 298 N.W.2d 500 (N.D. 1980); Bankers Indem. Ins. Co. v. Cleveland Hardware \& Forging Co., 77 Ohio App. 121, 62 N.E.2d 180, appeal dism'd, 145 Ohio St. 615, 62 N.E.2d 251 (1945); Harter Concrete Prods., Inc. v. Harris, 592 P.2d 526 (Okla. 1979); Arnold v. Borbonus, 257 Pa. Super. 110, 390 A.2d 271 (1978); Cacchillo v. H. Leach Mach. Co., 111 R.I. 593, 305 A.2d 541 (1973); Curtis v. Harmon Elec., Inc., 552 P.2d 117 (Utah 1976); Virginia Elec. \& Power Co. v. Wilson, 221 Va. 979, 277 S.E.2d 149 (1981); Seattle First Nat'l Bank v. Shoreline Concrete Co., 91 Wash.2d 230, 588 P.2d 1308 (1978) (en banc); Mulder v. Acme-Cleveland Corp., 95 Wis.2d 173, 290 N.W.2d 276 (1980).

18. The accent here is on "liable." Thus, statutes based on the Uniform Contribution Among Tortfeasors Act (Uniform Act), define joint tortfeasors as two or more persons "jointly or severally liable in tort." UNIF. CONTRIBUtion AMONG TORTFEASORS ACT $\S 1,12$ U.L.A. 63 (1955).

19. See, e.g., Farren v. New Jersey Turnpike Auth., 31 N.J. Super. 356, 106 A.2d 752 (1954). 
As a legal proposition, this doctrine has stood the test of time, on the whole, very well. As we shall see, there have been one or two defections, but usually, when the result of the doctrine has been thought inequitable, the remedy has taken the form either of ad hoc legislation or of solutions based on some sort of indemnity concept.

In a number of states in which the doctrine was well established, the intervening adoption of comparative negligence has been seized upon as a basis for attempting to change the rule; these attempts have been consistently unsuccessful. ${ }^{20}$ There is nothing in the embracing of comparative negligence that implies any intention to alter the fundamental principle of exclusiveness of compensation liability.

\section{Limited Contribution: Minority Rule Permitting}

\section{A. Early Federal Cases.}

Except for several contra holdings in federal district courts, ${ }^{21}$ the basic doctrine went unchallenged until the appearance of the Third Circuit's opinion in Baccile v. Halcyon Lines ${ }^{22}$ in 1951. The views expressed in this opinion, although the case itself was reversed by the Supreme Court, ${ }^{23}$ are sufficiently stimulating to deserve attention, par1979).

20. See, e.g., General Elevator Corp. v. Champion Papers, 590 S.W.2d 763 (Tex. Civ. App.

21. See, e.g., The S.S. Samovar, 72 F.Supp. 574 (N.D. Cal. 1947); Rederii v. Jarka Corp., 26 F. Supp. 304 (D. Me. 1939).

22. 187 F.2d 403 (3d Cir. 1951), rev'd sub nom. Halcyon Lines v. Haenn Ship Ceiling \& Refitting Corp., 342 U.S. 282 (1952).

23. Halcyon Lines v. Haenn Ship Ceiling \& Refitting Corp., 342 U.S. 282 (1952). The actual ground of the Supreme Cour's reversal did not reach the limited contribution issue, which is the one of interest to workers' compensation law, but rather involved a narrow point of admiralty law. The Supreme Court ruled that the admiralty doctrine under which mutual wrongdoers share the damages equally did not extend to noncollision cases such as this one. At the same time, by way of dictum, the Court cast a cloud over the arbitrary selection of amount of compensation liability as the amount of contribution liability when it observed that, even if there were a fresh legislative solution of the problem of contribution in noncollision cases,

there would still be much doubt as to whether application of the rule or the amount of contribution should be limited by the [Longshoremen's and] Harbor Workers' [Compensation] Act, or should be based on an equal division of damages, or should be relatively apportioned in accordance with the degree of fault of the parties.

342 U.S. at 286-87.

Sooner or later a case had to come along involving a collision, thus making it impossible to avoid deciding the contest between the admiralty moiety rule and the compensation exclusiver liability defense. In Weyerhaeuser S.S. Co. v. United States, 372 U.S. 597 (1963), the Court held that the moiety rule in admiralty takes precedence over the exclusive-liability defense under a compensation act. The moiety rule is in effect taken out of the company of the contribution cases and assimilated to the Ryan-type of independent-indemnity-duty cases. See text accompanying notes 8-10 supra. The key factor here is that the moiety obligation, unlike contribution between tortfeasors generally, is indeed a separate duty based, not on the two wrongdoers' mutual relation to the plaintiff, but on their relation to each other. This was crisply brought out in the first leading 
ticularly since this was a sincere attempt to work out a sort of compromise to minimize the apparent unfairness of an all-or-nothing disposition of the recovery-over problem. The court pointed out at once that the tort liability here was in admiralty, a system which has developed rules according to its own sense of right, including its distinctive "moiety rule" applicable to mutual wrongdoers. ${ }^{24}$ The requirement of common liability was not, therefore, quite as sacred in an admiralty setting as it might be at common law. The court then stated the heart of its position and its answer to the conventional recoveryover reasoning summarized above: "While Haenn [the employer] was responsible to Baccile [the employee] regardless of its fault, Haenn's negligence in fact brought to fruition his right to compensation. In a pragmatic sense, therefore, Haenn and Halcyon [the third party] were, to use the preferable admiralty law description, 'mutual wrongdoers'."2s

It was next stressed that the policy of compensation acts was not to relieve the employer of all liability, but rather to limit his liability to the amounts specified in the act. And so the court, pragmatic to the last, concluded that it would allow the third party a recovery of contribution from the employer, but would limit the amount to the sum which the employer would have been liable to pay the employee in compensation. ${ }^{26}$ The court thus partly avoided the dilemma posed by the two irreconcilable positions described at the outset, for at least the third party was not left to bear the entire burden alone.

case to interpret the scope of Weyerhaeuser S.S. Co. v. United States. In United Air Lines, Inc. v. Wiener, 335 F.2d 379 (9th Cir.), cert. dismissed sub. nom, United Air Lines, Inc. v. United States, 379 U.S. 951 (1964), as a result of a collision between a military plane and a United Air Lines plane, compensation was paid by the United States for the deaths of the government employees aboard the airline's plane under the Federal Employees' Compensation Act. In a third-party suit against United by representatives of the deceased employees, United sought recovery-over against the United States. The court held the recovery-over barred, both on the theory of indemnity and on the theory of contribution, as to which Weyerhaeuser S.S. Co. v. United States had been heavily relied on by the airline. In distinguishing it, the court said:

The admiralty rule of divided damages is to be distinguished from the rule of indemnity urged upon us by United since under admiralty law there arises from a collision involving mutual fault the right to apportionment of all damages resulting therefrom, including personal injuries, cargo damage, and damage to ships. The divided damage rule is based upon the duty which each shipowner owes the other to navigate safely irrespective of any duty to the person injured.

335 F.2d at 403 (emphasis added).

24. 187 F.2d at 404.

25. Id. at 406.

26. Id. 


\section{B. The Former "Pennsylvania Rule".}

Pennsylvania at one time had a similar rule, based on a unique theory of contribution, which held that contribution between joint tortfeasors under the Uniform Contribution Among Tortfeasors Act (Uniform Act) depended not on joint liability but on joint negligence. ${ }^{27}$ To put the matter a little more exactly, one may quote Justice Roberts of the Supreme Court of Pennsylvania: "Implicit in these holdings is the view that the definition of 'joint tortfeasors' does not require that they have a common liability toward the injured party but only that their combined conduct be the cause of the injury." 28 It will be readily observed that this rule was in conflict with that described earlier as the normal rule, based as it is on the fact that the Uniform Act actually uses the term "jointly . . . liable in tort."29 Once the requirement of joint liability is removed, the employer's defense based on absence of liability to the employee collapses. Pennsylvania, before abolishing by a 1974 amendment not only contribution against the employer but implied indemnity as well, ${ }^{30}$ accordingly produced a series of cases allowing the third-party action over against the employer in contribution-but it also arbitrarily limited the amount of contribution to the amount of the employer's compensation liability. ${ }^{31}$ This former Pennsylvania rule thus involved not one tour de force but two. First, to get contribution at all, the statutory language "liable in tort" had to be held to mean not liable but guilty of having contributed to a tort. Second, to keep the amount of contribution from being open-ended, it had to be limited to the employer's compensation liability; and, since there was really no strictly legal rationale requiring this limitation, the limitation had to be arbitrarily imposed for reasons of policy.

This result is exactly what the Third Circuit set out to produce and

27. See Elston v. Indus. Lift Truck Co., 420 Pa. 97, 102 n.2, 216 A.2d 318, 320 n.2 (1966).

28. Id.

29. See note 18 supra.

30. Section 303(b) of the Pennsylvania Workmen's Compensation Act, as amended in 1974, provides:

In the event injury or death to an employee is caused by a third party, then such employee, his legal representative, husband or wife, parents, dependents, next of kin, and anyone otherwise entitled to receive damages by reason thereof, may bring their action at law against such third party, but the employer, his insurance carrier, their servants and agents, employees, representatives acting on their behalf or at their request shall not be liable to a third party for damages, contribution or indemnity in any action at law, or otherwise, unless liability for such damages, contributions or indemnity shall be expressly provided for in a written contract entered into by the party alleged to be liable prior to the date of the occurrence which gave rise to the action.

PA. Stat. ANn. tit. 77, § 481(b) (Purdon Supp. 1981).

The constitutionality of the amendment was upheld in Tsarnas v. Jones \& Laughlin Steel Corp., 488 Pa. 513, 412 A.2d 1094 (1980).

31. See, e.g., Socha v. Metz, 385 Pa. 632, 123 A.2d 837 (1956). 
did produce in the Baccile case. ${ }^{32}$ The Third Circuit got past the nocontribution problem by applying the admiralty moiety rule, and surmounted the limitation problem by the simple expedient of decreeing the limitation for practical and policy reasons. ${ }^{33}$ The Supreme Court reversed on the first point ${ }^{34}$ and cast doubt on the second, saying that, even if there were a legislative treatment of the problem, there would still be a question whether the amount of contribution should be the amount of compensation, or half, or an amount proportioned to degree of fault. 35

\section{The Minnesota Rule in Lambertson.}

The Supreme Court of Minnesota, in the 1977 case Lambertson $v$. Cincinnati Corp. ${ }^{36}$ also adopted the result-oriented approach, and concluded that the result most equitable and most consonant with compensation policy was to allow contribution by the employer in proportion to his fault, but in no event beyond his workers' compensation liability. ${ }^{37}$ Acknowledging that there was no "common liability" of the kind classically required to support contribution, the court argued that the employer and third party were nevertheless both liable in their own way to the employee, that contribution was an equitable doctrine, and that outworn technical concepts like common liability should not be allowed to stand in the way of a fair result. ${ }^{38}$ The result was also consistent with compensation policy, in that the employer's liability remained limited to that allowed under the compensation act.

32. 187 F.2d 403 (3d Cir. 1951), rev'd sub nom. Halcyon Lines v. Haenn Ship Ceiling \& Refitting Corp., 342 U.S. 282 (1952). See notes 22-26 supra and accompanying text.

33. 187 F.2d at 406.

34. Halcyon Lines v. Haenn Ship Ceiling \& Refitting Corp., 342 U.S. 282, 285-86 (1952).

35. Id. at 286-87.

36. 312 Minn. 114, 257 N.W.2d 679 (1977). Cincinnati sold a press brake to the plaintif's employer. The plaintiff was injured while operating the machine. After recovering workmen's compensation from his employer, the plaintiff brought a negligence action against Cincinnati. Id. at 116, 257 N.W.2d at 682. The jury found all parties causally negligent as follows: Plaintiff15\%; Cincinnati-25\%; Employer-60\%. Damages of $\$ 40,000$ were awarded. Judgment was ordered against Cincinnati for $\$ 34,000$, the full amount of the verdict less $15 \%$. Id. at 117, 257 N.W.2d at 683 . Cincinnati then sought indemnity or contribution from the employer as a thirdparty tortfeasor, which the lower court denied on the authority of Hendrickson v. Minnesota Power \& Light Co., 258 Minn. 368, 104 N.W.2d 843 (1960), overruling Tolbert v. Gerber Indus. Inc., 255 N.W.2d 362 (Minn. 1977). The supreme court, acknowledging the evenly-balanced controversy surrounding third-party indemnity actions, found no "continuing persuasive force in the reasoning of the court in Hendrickson." Lambertson, 312 Minn. at 127-28, 257 N.W.2d at 688.

37. Id. at 130,257 N.W.2d at 689.

38. Id. at $128-30,257$ N.W.2d at $688-89$. 


\section{The California and North Carolina Approach.}

If it is postulated that the compromise result temporarily achieved in the Third Circuit by Baccile and in Pennsylvania is desirable, there is a shortcut that might seem to put all the parties in this same position with less waste of motion. This is the rule adopted in North Carolina ${ }^{39}$ and California ${ }^{40}$ under which, when the employer's negligence contributed to the injury, the employee's third-party recovery is merely reduced by the amount of compensation. Suppose the third-party verdict is $\$ 10,000$, and the compensation outlay is $\$ 3,000$. Under the former Pennsylvania contribution rule, the employer would pay the employee $\$ 3,000$, the third party would pay the employee $\$ 10,000$, the employee would pay back the $\$ 3,000$ to his own employer, and the third party would recover $\$ 3,000$ from the employer as contribution. At the end of the process, the employee would have $\$ 10,000$, the employer would have parted with $\$ 3,000$, and the third party would have paid $\$ 7,000$. Under the North Carolina rule, the employee would merely keep the $\$ 3,000$, then collect $\$ 7,000$ from the third person.

This is a judge-made rule, based primarily on the general idea that no one should profit by his own wrong. In California, the decision was based also on approval of the results produced by both North Carolina and Pennsylvania precedents. ${ }^{41}$ Moreover, since the California decision involved overruling earlier precedents, the court cited the intervening legislative abrogation of the noncontribution rule $e^{42}$ as a ground for the new holding. One reason that had been given for the older rule, denying any reduction of the third party's liability to the employee when the employer was negligent, was that the third party at that time could not have recovered contribution from the employer in any case. ${ }^{43}$ of course, quite apart from the availability or nonavailability of contribution, the earlier rule could also have been arrived at on the familiar legal theory that the cause of action is the employee's in any event, and therefore his full recovery should not be affected by his employer's negligence. ${ }^{44}$ However, the intervention of the contribution amendment

39. Hunsucker v. High Point Bending \& Chair Co., 237 N.C. 559, 75 S.E.2d 768 (1953). In North Carolina, the reduction applies when there is an actively negligent employer.

40. Tate v. Superior Court of Los Angeles, 213 Cal. App. 2d 238, 28 Cal. Rptr. 548 (1963).

41. Witt v. Jackson, 57 Cal. 2d 57, 366 P.2d 641, 17 Cal. Rptr. 369 (1961). It is significant that the opinion lumps together the North Carolina and Pennsylvania doctrines, as is in effect done here, in spite of the different mechanisms involved in reaching a comparable end product. $I d$. at 71, 366 P.2d at 649, 17 Cal. Rptr. at 377.

42. CAl. CODE Civ. Proc. $\$ \S 875-880$ (West 1980).

43. Pacific Indem. Co. v. California Elec. Works, 29 Cal. App. 2d 260, 84 P.2d 793 (1938).

44. See A. LARSON, WorKMEN's COMPENSATION $\$ \$ 75.21-22$ (1982). 
gave California a legal handle with which to steer its rule in what it was convinced was a more equitable direction.

The California approach was intended to save wasted motion, yet in practice it did just the opposite, setting off a flood of confusion and litigation that continues to this day. ${ }^{45}$ Several courts, including the Supreme Court of the United States, ${ }^{46}$ and the supreme courts of New Jersey ${ }^{47}$ and Arizona, ${ }^{48}$ have deliberately declined to emulate California's well-intended effort.

\section{E. The "Murray Credit" Rule.}

A quite different legal path to a somewhat different compromise solution was adumbrated by the Court of Appeals for the District of Columbia Circuit, in a passage which is something more than a dictum and something less than the ratio decidendi of the case in which it appears. In Murray v. United States ${ }^{49}$ the plaintiff employee was injured in the fall of an elevator, and received compensation under the Federal Employees' Compensation Act. He then sued the building owner, Murray, who had leased the building to the United States. Murray counterclaimed against the United States both for contribution and for indemnity under the provisions of the lease. Summary judgments dismissing both counts were affirmed.50 As to contribution, Judge Leventhal emphatically concluded that it was ruled out by the exclusive-remedy principle, since contribution was only possible "when the tortfeasors have a concurring liability to the same victim." $\$_{1}$ At this point, however, without any warning that a sensational legal innovation was about to be unveiled, Judge Leventhal said:

Any inequity residing in the denial of contribution against the employer is mitigated if not eliminated by our rule in Martello v. Hawley, 112 U.S. App. D.C. 129, 300 F.2d 721 (1962). Martello holds that where one joint tortfeasor causing injury compromises the claim, the other tortfeasor, though unable to obtain contribution because the

45. See id. $\$ 75.22$ (1982).

46. See Edmonds v. Compagnie Generale Transatlantique, 443 U.S. 256 (1979), rev'g 577 F.2d 1153 (4th Cir. 1978). A longshoreman, employed by a stevedoring company, was injured while working aboard a ship. The longshoreman brought a tort suit alleging negligence by the shipowner. A jury found that the stevedoring company's negligence contributed $70 \%$ of the fault, the ship's 20\%, and the longshoreman's 10\%. On rehearing, sitting en banc, the Court of Appeals for the Fourth Circuit adopted a comparative negligence standard and held that the shipowner could be required to pay only that proportion of the total damages that matched its proportion of fault. This decision was reversed by the Supreme Court. 443 U.S. at 273.

47. Schweizer v. Elox Div. of Colt Indus., 70 N.J. 280, 359 A.2d 857 (1976).

48. Stroud v. Dorr-Oliver, Inc., 112 Ariz. 403, 542 P.2d 1102 (1975).

49. 405 F.2d 1361 (D.C. Cir. 1968).

50. Id. at 1365.

51. Id. 
settling tortfeasor had "bought his peace," is nonetheless protected by having his tort judgment reduced by one-half, on the theory that one-half of the claim was sold by the victim when he executed the settlement. In our situation if the building owner is held liable the damages payable should be limited to one-half of the amount of damages sustained by the plaintiff, assuming the facts would have entitled the owner to contribution from the employer if the statute had not interposed a bar. A tortfeasor jointly responsible with an employer is not compelled to pay the total common law damages. The common law recovery of the injured employee is thus reduced in consequence of the employee's compensation act, but that act gave him assurance of compensation even in the absence of fault. ${ }^{52}$

This provocative passage deserves close analysis as one more way of trying to find a compromise between the evenly-balanced interests of the third party, the employer, and the employee. The analysis should consider both legal and policy arguments.

On the legal side, the first question is how much decisional force the quoted paragraph has. It does not decide a point at issue in the case before the court. On the other hand, it is in a sense more than obiter dictum, since the court in part justifies the harshness of its main decision blocking contribution by giving the third party this consolation prize. At the same time, it cannot be said that this statement was necessary to the decision. The central decision barring contribution could have been made without it-indeed would have had to be made even without it, under the reasoning of the court and the authorities cited. On the whole, then, while the statement is more than dictum, it is not much more, which is probably just as well, as we shall see presently.

The real legal problem is not even discussed by the court. This is the question whether a rule designed for covenants not to sue can automatically be assumed to apply to the workmen's compensation problem. The problem of the joint tortfeasor with an individual defense to the plaintiff is encountered as to five principal defenses: nonliability because the injured party is an employee of one of the joint tortfeasors; nonliability because one of the tortfeasors has given plaintiff a covenant not to sue; nonliability because of personal relationship between the plaintiff and one of the tortfeasors; nonliability because, as to one tortfeasor, the plaintiff had assumed the risk; and nonliability of one tortfeasor because as to him the statute of limitations has run or the

52. Id. at 1365-66 (footnotes omitted). The Martello rule is not accepted by the UNIF. CoNTRIBUTION AMONG TORTFEASORS ACT \& 4, 9 U.L.A. 111, 118-19 (Supp. 1963). It has, however, been adopted in New Jersey, Judson v. Peoples Bank \& Trust Co., 17 N.J. 67, 110 A.2d 24 (1954), and in Texas, Palestine Contractors, Inc. v. Perkins, 386 S.W.2d 764 (Tex. 1964). See also, Note, Contribution Among Joint Tortfeasors When One Tortfeasor Enjoys a Special Defense Against Action by the Injured Party, 52 CORNell L.Q. 407 (1967). 
period for giving notice of injury has expired. ${ }^{53} \mathrm{~A}$ mere glance at the list is enough to reveal that the competing interests and legal considerations vary sharply from one category to another, and it can by no means be assumed that a solution suitable to one category should or will be adopted for the others. ${ }^{54}$ For example, Louisiana has decided that a tortfeasor protected from direct suit by the plaintiff as a result of interspousal immunity may be held liable for contribution, ${ }^{5 s}$ but that a tortfeasor shielded by the exclusive-remedy defense of workmen's compensation may not be. ${ }^{56}$ There are many differences between the compensation category and the covenant-not-to-sue category. They do have one thing in common, as the author pointed out in an article published in 1940: in these two categories the plaintiff gets something from the immunized tortfeasor; in the others he does not. ${ }^{57}$ But there the resemblance ends. The chief difference is that the plaintiff giving a covenant not to sue is making a voluntary choice. He can do it or not do it, and he can control the circumstances under which it is done; if he does not like the legal consequences he can protect himself by merely refraining from giving the covenant. The employee in the Murray case had no such option. His third-party recovery is cut down by the court's act, not by his act. This distinction goes to the heart of what is probably the primary reason for the Martello-type rule. Mr. Justice Brennan stressed it when, as a Justice of the Supreme Court of New Jersey, he wrote the opinion in the leading case establishing the rule in New Jersey: "if the injured party is required to credit only the amount received in settlement . . . he may be tempted to make collusive settlements. ..."58 And Judge Bastian in Martello, referring to the decision about to be reversed, said, as his first argument: "We think the holding of the Municipal Court of Appeals would leave the door too far open to fraud and collusion." 59 Plainly, this rationale for the Martello rule has little relevance to the situation in the Murray case. The employee has no choice whether his injury should be under the compensation act, and his employer's liability under that act is fixed by law.

53. See Larson, A Problem in Contribution: The Tortfeasor With an Individual Defense Against the Injured Party, 1940 Wis. L. REv. 467, 467-68 (1940). See also, Note, Contribution Among Joint Tortfeasors When One Tortfeasor Enjoys a Special Defense Against Action by the Injured Party, 52 CORNELl L.Q. 407 (1967).

54. See instances cited in Larson, supra note 53 and Note, supra note 53, at 408-12, where a jurisdiction's holdings vary depending on the category.

55. Smith v. Southern Farm Bureau Cas. Ins. Co., 247 La. 695, 174 So.2d 122 (1965).

56. Pálmer v. Willemet-Stouse Elec. Co., 183 So.2d 373 (La. App. 1966), cert. denied, 249 La. 67, 184 So.2d 736 (1966).

57. See LARSON, supra note 53.

58. Judson v. Peoples Bank \& Trust Co., 17 N.J. 67, 92, 110 A.2d 24, 36 (1954).

59. Martello v. Hawley, 300 F.2d 721, 723 (D.D.C. 1962). 
Another obvious dissimilarity between the covenent-not-to-sue situation and exclusive-remedy problem is that the plaintiff in the former is allowed to keep the proceeds both of his settlement and of his damage recovery, while in the latter he must restore so much of the damage recovery to his employer as represents the compensation outlay. Assume the total damages are $\$ 20,000$, and the plaintiff settles with the first tortfeasor for $\$ 9,000$. His recovery against the second tortfeasor under Martello would be $\$ 10,000$. Thus, he would have and retain $\$ 19,000$. But, if the plaintiff had received $\$ 9,000$ in workmen's compensation under Murray, the employee would have to pay $\$ 9,000$ over to the employer out of his $\$ 10,000$ recovery, leaving him with a total recovery of compensation plus damages of only $\$ 10,000$.

On the practical and policy side, the prime defect of the Murray result is that there is no rational relation between the fifty percent reduction in plaintiff's recovery and the interests of either the employee or the employer. Let us go back to the facts of the Kittleson case ${ }^{60}$ with which this article opened. The compensation liability there was $\$ 6,800$ and the third-party recovery was $\$ 60,000$. If this situation were to arise under the Murray case, the plaintiff, instead of recovering $\$ 60,000$ and reimbursing the employer for $\$ 6,800$, thus retaining $\$ 53,200$, would recover only $\$ 30,000$ from the third party, plus his $\$ 6,800$ compensation, for a total of $\$ 36,800$-in spite of the fact that at the trial he must be assumed to have established actual damages of $\$ 60,000$. By what conceivable logic can he be told that he should absorb a loss of $\$ 16,400$ for the benefit of the third-party tortfeasor? A rule capable of producing such a result is clearly unacceptable, particularly since its legal underpinnings are just as unsound as its practical result, and it is accordingly not surprising that the "Murray credit" rule, although frequently invoked, has attracted no further acceptance. ${ }^{61}$

\section{F. The New York Rule in Dole.}

In 1972 the New York Court of Appeals, in Dole v. Dow Chemical Co. ${ }^{62}$ held that the third-party defendant in a suit by the employee's widow could implead the employer, who was partially responsible for the employee's death, and recover from the employer an amount proportionate to the employer's share of fault. Since, for purposes of the exclusive-remedy clause, the court treated this as a case of indemnity

60. See notes 2-4 supra and accompanying text.

61. See Arcell v. Ashland Chem. Co., 152 N.J. Super. 471, 378 A.2d 53 (1977). See also Dodge v. Mitsui Shintaku Ginko K.K. Tokyo, 528 F.2d 669 (9th Cir. 1975), cert. denied, 425 U.S. 944 (1976).

62. 30 N.Y.2d 143, 282 N.E.2d 288, 331 N.Y.S.2d 382 (1972). 
rather than contribution, a detailed analysis of this landmark decision must be reserved for inclusion in the discussion of implied indemnity growing out of a tort situation. ${ }^{63}$ But at this point it must be noted that, for all the court's repeated references to "indemnity," it has in effect revolutionized the sharing of damages between joint wrongdoers in New York. Previously, New York had employed the "active-passive" negligence test in deciding when indemnification would be allowed, 64 had found an implied contract in favor of the wrongdoers who had been passively negligent and against the actively negligent wrongdoers, ${ }^{65}$ and had asserted that this was something different from contribution. Now there appears to be an implied contract of indemnity in favor of any tortfeasor by any other tortfeasor, whatever their degrees of responsibility. It is difficult to see what remains to be handled under the regular contribution statute ${ }^{66}$ apportioning damages equally between joint tortfeasors. In other words, Dole strikes two resounding blows in favor of flexibility. First, it replaces contribution, and its rigid pro rata rule on sharing liability, with indemnity, at least in any case in which a party has insisted on having indemnity determined in the judgment. Second, it replaces the previous all-or-nothing outcome in indemnity with proportionate-responsibility sharing.

A discussion of the issue of tort law in this decision is out of place here. Accepting this tort law tour de force as an accomplished fact, and reserving the question of the compensation law exclusive-remedy issue, ${ }^{67}$ one may at this point merely note how, in a typical case, the Dole rule attempts to achieve a rough equity among the parties. Suppose the total damages were $\$ 20,000$, and suppose claimant has received $\$ 9,000$ in workmen's compensation. The third party, let us assume, was $40 \%$ responsible for the loss, and the employer $60 \%$. The employee would recover his full $\$ 20,000$ from the third party in the tort suit. Out of this, the third party would eventually pay only $\$ 8,000$, which is calculated in relation to his fault. The employer would pay $\$ 12,000$, which is also calculated in relation to his fault. But in New York, fault or no fault, the employer would have a right to reimbursement of his compensation outlay from the proceeds of the third-party suit, and so he would get back $\$ 9,000$ from the employee. This prevents a double recovery by the employee, who is now left with $\$ 20,000$, the exact amount of his loss. The employer has finally paid a total of $\$ 12,000$, which is a little
63. See text accompanying notes $280-84$ infra.
64. See McFall v. Compagnie Maritime Belge, 304 N.Y. 314, 107 N.E.2d 463 (1952).
65. Id. at 328,107 N.E.2d at 471.
66. N.Y. Crv. Prac. LAW $\$ 1401$ (McKinney 1976).
67. See text accompanying notes $285-87$ infra. 
more than he would have paid under a cast-iron exclusiveness rule, but much less than he would have paid out if his $60 \%$ negligence had been called the "active" and "primary" negligence, saddling him with the entire tort liability under the old rule.

\section{G. The Illinois Rule in Skinner and the 1979 Amendment.}

It remained for the Supreme Court of Illinois, in Skinner v. ReedPrentice Division Package Machinery Co. ${ }^{68}$ to go all the way in demolishing the familiar no-contribution rule, by decreeing contribution, as contribution and not as indemnity, in proportion to fault, and without limitation to the amount of compensation liability. ${ }^{69}$ Thus, it outdid both Minnesota's Lambertson ${ }^{70}$ and New York's Dole. ${ }^{71}$ Lambertson was just as uninhibited in scrapping the conventional rule requiring common liability before there could be contribution, but it was more limited in that the ceiling on the employer's liability was the amount of compensation. ${ }^{72}$ Dole was just as unlimited as Skinner in this latter respect, in that no ceiling was imposed, but was less spectacular in that, by using the indemnity vehicle, it did not have to shatter the common liability contribution doctrine, at least by name.73

Shortly after Skinner, the Illinois legislature adopted a general statute on contribution among joint tortfeasors. ${ }^{74}$ It makes no reference to the Skinner problem, but its language clearly does not support contribution on the Skinner facts. It authorizes contribution "where 2 or more persons are subject to liability in tort arising out of the same injury. . . ."75 Moreover, it is no coincidence that, although the effec-

68. 70 Ill.2d 1, 374 N.E.2d 437, cert. denied, 436 U.S. 946 (1978). The claimant brought a strict liability action for damages against the manufacturer of the machine on which she was injured. Although the claimant was barred from bringing such an action against her employer, the manufacturer filed a third-party complaint seeking contribution from that employer, based on misuse of the product. In a significant reworking of Illinois law, the court held that the third-party action was maintainable and that contribution from the employer in proportion to his relative degree of fault was proper. The court said that, although the complaint was cast in terms of negligence, it alleged misuse of the product and assumption of risk by the employer. Since an action over the indemnity would lie, under Miller v. De Witt, 37 Ill.2d 273, 226 N.E.2d 630 (1967), the court saw no reason why contribution should not also be available. 70 Ill. $2 d$ at 16,374 N.E.2d at 443.

69. Id.

70. 312 Minn. 114, 257 N.W.2d 679 (1977).

71. 30 N.Y.2d 143, 282 N.E.2d 288, 331 N.Y.S.2d 382 (1972).

72. 312 Minn. 114, 257 N.W.2d 679 (1977).

73. 30 N.Y.2d 143, 282 N.E.2d 288, 331 N.Y.S.2d 382 (1972).

74. An Act in Relation to Contribution Among Joint Tortfeasors, Ill. Rev. STAT. Ch. 70, $\S 302$ (1979). The right is only in favor of a tortfeasor who has paid more than his pro rata share, and is limited to the amount he has paid in excess of his pro rata share.

75. Id. (emphasis added). 
tive date of the amendment was September 14, 1979, it was made applicable to causes of action arising on or after March 1, 1978- the exact date of the Skinner decision. ${ }^{76}$

The amendment, of course, affects recovery-over only in the form of contribution. The remedy in the form of indemnity ${ }^{77}$ remains.

A post-amendment appellate division case, Marchi $v$. Indiana Harbor Belt R.Co. ${ }^{78}$ is a reminder that a version of active-passive or primary-secondary negligence indemnification is still alive in Illinois, although there must be a qualitative difference between the negligence of the parties.

We will return at the end of the article to an overall analysis of the relative merits of the many ingenious solutions that have been essayed, in the never-ending effort to strike the best balance in compensation's most evenly-balanced controversy. But first it is necessary to examine the second major category of such solutions, those centering on the concept of indemnity rather than contribution, where developments have been, if anything, even more dramatic and varied.

\section{INDEMNITY: EXPRESS CONTRACT}

\section{A. Normal Rule: Express Indemnity Not Barred.}

The third party may recover over against the employer whenever it can be said that the employer breached an independent duty toward the third party and thus acquired an obligation to indemnify the third party.

The clearest exception to the exclusive-liability clause is the third party's right to enforce an express contract in which the employer agrees to indemnify the third party for the very kind of loss that the third party has been made to pay to the employee. ${ }^{79}$ A familiar exam-

76. Id.

77. Miller v. De Witt, 37 Ill.2d 273, 226 N.E.2d 630 (1967).

78. 83 Ill. App. 3d 1005, 404 N.E.2d 938 (1980).

79. See Olsen v. Shell Oil Co., 595 F.2d 1099 (5th Cir.), cert. denied, 444 U.S. 979 (1979); Porello v. United States, 153 F.2d 605 (2d Cir. 1946), affd in part, rev'd in part, remanded sub nom. American Stevedores, Inc. v. Porello, 330 U.S. 446 (1947); American Radiator \& Standard Sanitary Corp. v. Mark Eng'g Co., 230 Md. 584, 187 A.2d 864 (1963); Liberty Mut. Ins. Co. v. Westerlind, 374 Mass. 524, 373 N.E.2d 957 (1978); Keefer v. Al Johnson Constr. Co., 292 Minn. 91,193 N.W.2d 305 (1971); De Shaw v. Johnson, 155 Mont. 355, 472 P.2d 298 (1970); City of Artesia v. Carter, 94 N.M. 311, 610 P.2d 198 (express contract of indemnity by a government body is not against public policy, and hence a government employer can be held to such a contract, although it has also paid workers' compensation), cert. denied, 614 P.2d 545 (1980); Gulf Oil Corp. v. RotaCone Field Operating Co., 84 N.M. 483, 505 P.2d 78 (Ct. App. 1972); Western Union Tel. Co. v. Cochran, 302 N.Y. 545, 99 N.E.2d 882, 102 N.Y.S.2d 65 (1951); Gibbs v. Carolina Power \& Light Co., 265 N.C. 459, 144 S.E.2d 393 (1965); Republic Steel Corp. v. Glaros, 12 Ohio App. 2d 29, 230 N.E.2d 667 (1967); Gordon H. Ball, Inc. v. Oregon Erecting Co., 273 Or. 179, 539 P.2d 1059 
ple is the situation in which an employee is injured because of the condition of the premises, and recovers from the landlord who leased the premises to the employer; if the landlord in the lease has exacted a covenant from the employer to hold the landlord harmless in the event of such claims, the enforcement of this covenant does not violate the exclusive-remedy provision of the compensation act. ${ }^{80}$ Another increasingly familiar example is the hold-harmless agreement assumed by a contractor doing work for a city ${ }^{81}$ or other owner, ${ }^{82}$ or by a subcontractor for the benefit of the general contractor. ${ }^{83}$ Indeed, with everyone trying to protect himself by such agreements, one may even encounter them in a series, along which liability travels until it settles upon the ultimate indemnitor. In Hardman v. Ford Motor Co. ${ }^{84}$ a subcontractor's employee was injured when the ladder on which he was standing slipped on a highly waxed floor. The contractor had furnished the ladder and was found negligent in not securing the ladder. The building owner was found negligent in not warning the employee of the highly polished surface. The subcontractor's employee successfully sued the contractor and the building owner. The owner cross-claimed against the general contractor on an indemnification agreement. The general contractor similarly filed a third-party complaint against the subcontractor for indemnification. The end result was that the injured employee's employer was held responsible for the judgment.

\section{B. The Minority Alabama Rule.}

It is characteristic of compensation law that, however one-sided a majority rule may be, it is almost never completely unanimous-and the rule here under consideration is no exception, thanks to the 1978 Alabama holding in Paul Krebs \& Associates v. Matthews \& Fritts Construction $\mathrm{Co}^{85}$ that even an express indemnity contract will not be enforced against the employer. ${ }^{86}$

The court's departure from the mainstream of workmen's compensation decisions began in 1976 with Gunter v. United States Fidelity \& Guaranty Co. ${ }^{87}$ That decision denied enforcement of an express in-

(1975); Redford v. City of Seattle, 94 Wash. 2d 198, 615 P.2d 1285 (1980); Young v. Anaconda Am. Brass Co., 43 Wis. 2d 36, 168 N.W.2d 112 (1969).

80. See Clements v. Rockefeller, 189 Misc. 889, 70 N.Y.S.2d 146 (N.Y. Sup. Ct. 1947).

81. See, e.g., Yearicks v. City of Wildwood, 23 N.J. Super. 379, 92 A.2d 873 (1952).

82. See, e.g., Republic Steel Corp. v. Glaros, 12 Ohio App. 2d 29, 230 N.E.2d 667 (1967).

83. See, e.g., Gordon H. Ball, Inc. v. Oregon Erecting Co., 273 Or. 179, 539 P.2d 1059 (1975).

84. 70 N.J. Super. 275,175 A.2d 455 (1961).

85. 356 So. $2 \mathrm{~d} 638$ (Ala. 1978).

86. Id. at 640 .

87. 340 So.2d 749 (Ala. 1977). 
demnity agreement against an employer when the third-party tortfeasor who sought to enforce the agreement was charged with active negligence. That decision was reaffirmed in Robins Engineering, Inc. $v$. Cockrell, ${ }^{88}$ which held that evidence of such an agreement was inadmissible in litigation by the employee against the third party. After these decisions, it seemed possible that the thrust of the court's holding would be limited to instances in which the third party was charged with active, rather than passive, negligence. However, the court's aberrational decisions reached their ultimate expression in Paul Krebs. In that case, the court interpreted the Alabama Workmen's Compensation Act $^{89}$ to forbid a third-party tortfeasor from recovering from an employer, even under an express contract of indemnity, for injury to an employee covered by the Act. ${ }^{90}$ Although the Paul Krebs case also dealt with facts evidencing active negligence by the third party, ${ }^{91}$ its holding is worded so generally that it seems to invalidate any indemnity contract, even if the third party were only passively or secondarily negligent. As authority for its holding, the court cited a lower appellate court case from New Mexico, Gulf Oil Corp. v. Rota-Cone Field Operation Co. ${ }^{92}$ Even before Paul Krebs, the Gulf Oil decision had been specifically repudiated by at least two state supreme courts. ${ }^{93}$ Then in 1980 it was repudiated by New Mexico itself. ${ }^{94}$ Thus the Supreme Court of Alabama now stands completely alone on this issue.

There are two principal grounds on which the validity of the express-indemnity exception has been attacked. The first, which succeeded in Alabama, is based on a literal interpretation of the exclusiveness clause, as being unqualified in its phrasing and therefore allowing no exceptions whatsoever. Outside of Alabama, this reading has generally been rejected. ${ }^{95}$ Public policy provides the other ground for attack. This rationale, that allowing third parties to escape contractually the consequences of their own wrongdoing offends sound public policy, has also been rejected in the reported cases in which it was attempted.96

\footnotetext{
88. 354 So.2d 1 (Ala. 1977).

89. AlA. CODE \& 25-5-53 (1975).

90. 356 So. $2 d$ at 640 .

91. Id. at 639.

92. 84 N.M. 483, 505 P.2d 78 (1972).

93. Manson-Osberg Co. v. State, 552 P.2d 654 (Alaska 1976); Gordon H. Ball, Inc. v. Oregon Erecting Co., 273 Or. 179, 539 P.2d 1059 (1975).

94. City of Artesia v. Carter, 94 N.M. 311, 610 P.2d 198 (Ct. App. 1980).

95. See, e.g., Republic Steel Corp. v. Glaros, 12 Ohio App. 2d 29, 230 N.E.2d 667 (1967).

96. See Olsen v. Shell Oil Co., 595 F.2d 1099 (5th Cir. 1979); Republic Steel Corp. v. Glaros, 12 Ohio App. 2d 29, 230 N.E.2d 667 (1967).
} 


\section{Specific Statutory. Treatment of Express Indemnity.}

Several state statutes, including those of California, ${ }^{97}$ North Carolina, ${ }^{98}$ Pennsylvania, ${ }^{99}$ and Texas, ${ }^{100}$ specifically provide that there shall be no right of recovery-over against the employer by a third person, whether by indemnity or contribution, in the absence of a written agreement entered into before the injury. Obviously, such a statute places the validity of the express-indemnity exception beyond question, and North Carolina has so held. ${ }^{101}$ As to the scope of the provision, California has taken the position that the provision rules out all nonexpress theories of liability over, whether related to implied contract or to equitable considerations based on tort. ${ }^{102}$ As to constitutionality, it has already been noted that the Pennsylvania statute survived constitutional attack. ${ }^{103}$ But the Minnesota version was struck down, principally because it was too broad, and because it deprived the third person of a common-law right of action without putting a reasonable substitute in its place. ${ }^{104}$

Express statutory treatment may also take the form, not of authorizing the express-indemnity exception, but of forbidding it, in whole or in part. An example of forbidding it wholly may be the sweeping Nevada provision stating: "No contract of employment, insurance, relief benefit, indemnity, or any other device, shall modify, change or waive any liability created by this chapter." 105 Whether or not the authors of this passage had the present problem in mind, the Supreme Court of Nevada has indicated in a dictum that an express contract of indemnity given by the employer would be void. ${ }^{106}$ An example of a partial ban of express indemnity contracts is contained in the 1972 Longshore-

97. Cal. LAB. CoDe $\$ 3864$ (West 1971). See Arbaugh v. Procter \& Gamble Mfg., 80 Cal. App. 3d 500, 506, 145 Cal. Rptr. 608, 613 (1978).

98. N.C. Gen. Stat. \& 97-10.2(c) (1979). See Gibbs v. Carolina Power \& Light Co., 265 N.C. $459,466-67,144$ S.E.2d $393,399-400$ (1965).

99. PA. Stat. ANn. tit. 77, § 481(b) (Purdon Supp. 1981-1982). See Bell v. Koppers Co., 481 Pa. 454, 457, 392 A.2d 1380, 1382 (1978).

100. TeX. Rev. Civ. Stat. AnN. art. 8306, \& 3 (Vernon 1966). See Ealand v. Gulf, C. \& S.F.Ry., 411 S.W.2d 591, 593 (Tex. Civ. App. 1967).

101. Gibbs v. Carolina Power \& Light Co., 265 N.C. 459, 466-67, 144 S.E.2d 393, 399-400 (1965).

102. San Francisco Examiner Div., Hearst Pub. v. Sweat, 248 Cal. App. 2d 493, 496-97, 56 Cal. Rptr. 711, 713-14 (1967).

103. Tsamas v. Jones \& Laughlin Steel Corp., 488 Pa. 513, 521, 412 A.2d 1094, 1096-99 (1980). See note 30 supra for the text of the statute.

104. Carlson v. Smogard, 298 Minn. 362, 367-69, 215 N.W.2d 615, 618-20 (1974).

105. Nev. Rev. StAT. $\$ 616.265$ (1979). The section goes on to say that all such devices are void.

106. Carrao Constr. Co. v. Curtis, 94 Nev. 569, 571, 584 P.2d 1303, 1304 (1978). 
men's Amendments. ${ }^{107}$ The principal purpose of the amendments, of course, was to obliterate the type of implied indemnity that had been created by Ryan, ${ }^{108}$ but for good measure the amendment stated that "any agreements or warranties to the contrary shall be void"109 which is plainly broad enough to cover express contracts. But the amendment covers only agreements between the stevedoring employer and the vessel. Accordingly, it has no effect on agreements between the employer and third parties other than the ship, such as an oil company, ${ }^{110}$ a grain elevator, ${ }^{111}$ or a scaffolding erector. ${ }^{112}$

\section{Employer Not Joinable as Indemnitor.}

Since the indemnity claim is by definition a separate legal cause, and, unlike the employer's contributory negligence, is not intertwined with the tortious incident itself, every precaution should be taken to see that the employee's own third-party rights are not prejudiced by the injection of this factor into his case. To this end, North Carolina has held that, under an express contract of indemnity running from plaintiff's employer to the third party, the third party cannot insist that the employer and the employer's insurer be joined in the plaintiff's action for purposes of enforcement of the right of indemnity. ${ }^{113}$ Plaintiff was employed by the construction company, which was doing work for the power company, and was injured by the negligence of an employee of the power company. He received workmen's compensation benefits and then sued the third-party power company. ${ }^{114}$ In this suit, the plaintiff was held entitled to have his cause tried without being encumbered by these additional parties and issues not germane to his cause of action. The court said: "There is not that community of action in these various causes of action which will permit them to be litigated in plaintiff's action."115

107. 1972 Amendments, supra note 13.

108. See notes $8-12$ supra and accompanying text.

109. 1972 Amendments, supra note 13.

110. Crutchfield v. Atlas Offshore Boat Serv., 403 F. Supp. 920 (E.D. La. 1975).

111. Gould v. General Mills, Inc., 411 F. Supp. 1181 (W.D.N.Y. 1976).

112. Nieves v. Douglas S.S., Ltd., 451 F. Supp. 407 (S.D.N.Y. 1978).

113. Gibbs v. Carolina Power \& Light Co., 265 N.C. 459, 144 S.E.2d 393 (1965).

114. Id. at 460,144 S.E.2d at 395 .

115. Id. at 469,144 S.E.2d at 401 . An interesting feature of this case is that the same insurance carrier that insured the construction company's compensation liability to the plaintiff also insured the construction company's liability to the third party under the indemnity contract. This provides an illustration of the complications that are increasingly becoming apparent as insurance companies turn up on different and conflicting sides of the same issue. For example, in this instance, the same insurance company was being asked to help actively defend against plaintiffs suit, in its capacity as insurer of the indemnity agreement (which explicitly imposed that obligation on the carrier), while it was also the carrier that would attempt to assert a right to be reim- 


\section{E. Indemnity Agreement Not a Third-Party Defense.}

$A$ fortiori, the third-party tortfeasor cannot defend on the ground that the employee's employer has contracted to indemnify defendant, and will thus have to pay both workmen's compensation and tort damages. ${ }^{116}$ If the employer wants to make that kind of contract, that is his affair; the employee's rights, however, cannot be affected by such an agreement. ${ }^{117}$ Moreover, having made this kind of agreement, the èmployer cannot then undo its effect and pass the burden back to the employee by piling yet another agreement on this relation-an agreement by the employee that he will not exercise his rights against the third party as to liabilities that the employer has indemnified. Since the statutes themselves cast ultimate liability on the third party, ${ }^{118}$ a contractual provision in the employment contract that in this situation the employee's exclusive remedy shall be workmen's compensation is void. An attempt to enforce such a provision through an injunction against further prosecution at law by the employee of his rights against the third-party indemnitee was struck down by the Court of Appeals of New York. ${ }^{119}$

\section{INDEMNITy Growing out of Separate Duty Based on RELATIONSHIP}

If the third party and employer stand in a special legal relationship that carries with it the obligation of the employer to indemnify the

bursed out of the proceeds of the very action it was asked to help resist. This kind of tangle is at least partly avoided by the decision in this case, which sees to it that the first step in the process, the action by the employee plaintiff himself, goes forward without the complicating presence of the parties and issues involved in the indemnity problem.

The problem cannot always be this easily sidestepped, however. Suppose the carrier insuring the indemnity obligation seeks to exercise its statutory right as subrogated carrier on the compensation risk to intervene in the employee's third-party suit? This question arose in Michigan. See Harrison v. Ford Motor Co., 370 Mich. 683, 122 N.W.2d 680 (1963). The court held that the carrier would not be allowed to intervene, on the theory that the carrier would be merely suing to collect that which it would have to pay under the indemnification coverage. The flaw in this reasoning is that it takes as already established the employer's negligence. Since the insurer only insured the employer's agreement to indemnify the third party if the third party was held liable to the employer's employees for injuries caused by the negligence of the employer-a typical insurance of indemnification agreement-the carrier would have an interest in proving that the employer had not in fact negligently contributed to the employee's injuries. If it could succeed in this, it would not be suing itself since it would have no liability as insurer of the indemnity.

116. Umnus v. Wisconsin Pub. Serv. Corp., 260 Wis. 433, 51 N.W.2d 42 (1952).

117. Id. at $441-42,51$ N.W.2d at 47.

118. See Cal. Lab. Code $\$ 3864$ (West 1971); N.C. Gen. Stat. \& 97-10.2(e) (1979); Pa. Stat. AnN. tit. 77, § 481(b) (Purdon Supp. 1981-1982); TeX. Rev. Civ. Stat. AnN. art. 8306, § 3 (Vernon 1966).

119. Western Union Tel. Co. v. Cochran, 302 N.Y. 545, 99 N.E.2d 882 (1951). 
third party, this relational right of indemnity may be enforced without offending the exclusive-remedy clause. Such a relationship is that of a bailee to a bailor. In a leading California case, ${ }^{120}$ the employer, driving a car belonging to the third party, ran into his own employee. The employee sued the third party as owner of the car, under an owner's liability statute. ${ }^{121}$ The third party then claimed the right of reimbursement from the employer, whose negligence was the actual cause of the injury. It was held that the bailee of an automobile had a separate obligation to hold the bailor harmless from damage arising out of the bailment, and this obligation extended to indemnification for imposition of third-party liability on the owner in the present circumstances. ${ }^{122}$

This type of case usually presents, in addition to the special legal relations flowing from the concept of bailment, an extreme contrast between genuine negligence in one party and the most technical and constructive sort of imputed negligence in the other. This contrast, rather than the specific implications of bailment, was stressed in a somewhat similar Minnesota case, Lunderberg v. Bierman. ${ }^{123}$ Mrs. Bierman had taken her newly-purchased automobile back to the dealer for a 2,000 mile check-up provided for by the contract of purchase. As part of the check-up, Ilstrup and Elder Lunderberg, two employees of the dealer, took the car out for a road test, and Elder Lunderberg was injured as a result of Ilstrup's operation of the car. Elder collected workmen's compensation, and then sued Ilstrup, and also Mrs. Bierman as the owner with whose permission the car was being operated, ${ }^{124}$ under the Minnesota statute imposing such liability on motor vehicle owners. ${ }^{125}$ Mrs. Bierman was allowed to implead the dealer, and was granted summary judgment against him on the ground that he was liable to indemnify Mrs. Bierman for any recovery by Elder Lunderberg against her. ${ }^{126}$ The Supreme Court of Minnesota affirmed. ${ }^{127}$ The court relied not only on Baugh v. Rogers, ${ }^{128}$ but on several cases in which there was a similar disparity between the relatively minor or technical fault of the

120. Baugh v. Rogers, 24 Cal. 2d 200, 148 P.2d 633 (1944).

121. Id. at 204, 148 P.2d at 636.

122. Id. at 214-16, 148 P.2d at 641-42.

123. 241 Minn. 349, 63 N.W.2d 355 (1954).

124. Id. at 351,63 N.W.2d at 357.

125. Minn. Stat. AnN. \& 170.54 (West 1960).

126. 241 Minn. at 351,63 N.W.2d at 357-58.

127. Id. at 349,63 N.W.2d at 355 .

128. 24 Cal. $2 d$ 200, 148 P.2d 633 (1944). 
third party and the active or primary negligence of the employer. 129 The ground of the decision, then, is not the narrow one of the specific obligation of a bailee to hold a bailor harmless, but is the broader principle stated as follows by the court:

[The impleaded defendant is liable] where, as here, the parties are not in pari delicto, but, instead, the injury arises out of a duty which one owes to the other so that as between themselves the act or omission of one is the primary cause of the injury and liability exists as to the other only by virtue of a law imposing such liability. ${ }^{130}$

It is interesting that the Minnesota Supreme Court, in later holding unconstitutional a Minnesota statute prohibiting recovery-over against an employer in the absence of a written indemnity agreement, ${ }^{131}$ displayed as its most horrible example of potential inequity a set of facts somewhat similar to those in Lunderberg. As a striking example of the kind of common law remedy destroyed without a reasonable substitute, the court narrated the following fact situation: (1) the employer sold a car to the third party in faulty condition; (2) after one of several service jobs done on the faulty car, an employee took the third party for a drive to show that the car was repaired; (3) during the trip the hood flew open, causing the employee to have a heart attack; (4) the employee sued the third party because of the negligently homemade hood latch; (5) the third party asserted in this third-party complaint that the sole cause was the negligent conduct of the employer in selling and servicing the car. ${ }^{132}$

New Jersey reached a conclusion similar to that in the bailment cases when the special relation was that of principal to agent, entailing the implied obligation of the principal to indemnify the agent for losses or liabilities attending the carrying out of the agency. ${ }^{133}$ The deceased employee's widow had brought a wrongful-death action against one of her husband's co-workers alleging negligence. ${ }^{134}$ The co-worker impleaded the employer as a third-party defendant on the ground that the employer would be liable to indemnify the co-worker for torts committed at the direction of the employer. The dismissal of the third-party suit was reversed. ${ }^{135}$ Although there could be no contribution between

129. American Dist. Tel. Co. v. Kittleson, 179 F.2d 946 (8th Cir. 1950); Burris v. American Chicle Co., 120 F.2d 218 (2d Cir. 1941); Westchester Lighting Co. v. Westchester County Small Estates Corp., 278 N.Y. 175, 15 N.E.2d 567 (1938).

130. 241 Minn. at 363,63 N.W.2d at 364.

131. Carlson v. Smogard, 298 Minn. 362, 369, 215 N.W.2d 615, 619-20 (1974).

132. Id. at $364-65,215$ N.W.2d at $617-18$.

133. Hagen v. Koemer, 64 N.J. Super. 580, 166 A.2d 784 (1960).

134. In New Jersey, a co-employee at that time was not immune and could be sued as a third party. $I d$. at $588,166 \mathrm{~A} .2 \mathrm{~d}$ at 788 .

135. Id. at $588-89,166 \mathrm{~A} .2 \mathrm{~d}$ at 788 . 
joint tortfeasors, indemnification would be allowed on the ground of an implied promise of indemnity by the principal for damages resulting to the agent from the execution of the agency. The court is careful to point out that, if this were a simple case of negligence on the part of the agent, indemnity would not apply. ${ }^{136}$ But if the agent in good faith performs a tortious act at his principal's direction, or if he commits a tortious act relying on his principal's representations as to its legal propriety, he is entitled to indemnity from the principal. ${ }^{137}$ Although in this case the pleadings were based on alleged negligence, the court felt that, for purposes of a motion to dismiss, the state of the factual record was not such as to exclude the possibility of a right of indemnity based on the separate duty of the principal to indemnify his agent for losses incurred in the execution of the agency. ${ }^{138}$

\section{IMPLIED CONTRACTUAL INDEMNITY}

When the employer's relation to the third party is that of a contractor doing work for the third party, there may be an implied obligation to perform the work with due care. If, by failing to use such care, the employer causes an accident injuring his own employee, it may be said that the employer has simultaneously breached two duties of care. The one is toward the employee, and it is for this breach that compensation bars any common-law remedy. The other is toward the thirdparty contractee, and among the damages flowing from the breach of this separate duty may be any damages the third party is forced to pay the employee because of their relation.

\section{A. Implied Contractual Indemnity under the Longshoremen's Act.}

1. Summary of the Longshoremen's Act Story. Between 1955 and 1972, this doctrine was associated with and strongly influenced by the decision of the United States Supreme Court in Ryan Stevedoring Co. v. Pan-Atlantic Steamship Corp. ${ }^{139}$ This case held, as indicated earlier, ${ }^{140}$ that in a contract to perform stevedoring operations, the stevedoring company impliedly agrees with the shipowner that it will both perform these services in a workmanlike way and will indemnify the

136. Id. at 588,166 A.2d at 788 .

137. See Restatement (SeCOND) of Agency § 439 (1958).

138. 64 N.J. Super. at 587,166 A.2d at 788.

139. 350 U.S. 124 (1956), affg 349 U.S. 901 (1955). This case was affirmed at 349 U.S. 901 by an equally divided Court. After reargument before a full Court it was affirmed at 350 U.S. 124 by a 5-to-4 vote, with Mr. Justice Black writing the dissenting opinion, in which Chief Justice Warren, Mr. Justice Douglas and Mr. Justice Clark joined.

140. See text accompanying notes 8-12 supra. 
shipowner for any liabilities he might incur as a result of the stevedoring company's failure to fulfill this promise. ${ }^{141}$

This "Ryan"-type of liability, together with dozens of cases stemming from the Ryan precedent, was abolished by Congress late in 1972. ${ }^{142}$ The abolition was in two steps, one affecting the employee's cause of action against the ship in the first place, the other affecting the Ryan liability-over of the longshoring employer. As to the first, it should be pointed out that the groundwork for this line of cases had been laid when the Supreme Court held in Seas Shipping Co. v. Sier$a c k i 143$ that the virtual nonfault liability of the ship for "unseaworthiness" extended to longshoremen. ${ }^{144}$ The Ryan triangle typically began with an unseaworthiness recovery by the employee against the ship. The 1972 Amendments strike directly at this beginning-point by providing: "The liability of the vessel under this subsection shall not be based upon the warranty of seaworthiness or a breach thereof at the time the injury occurred. The remedy provided in this subsection shall be exclusive of all other remedies against the vessel except remedies available under this Act." 145

There remains, of course, the possibility of a suit by the employee against the ship based on negligence rather than unseaworthiness. The 1972 Amendments recognize this possibility, while placing a special limitation on such liability, but then proceed immediately to knock out any derivative Ryan-type recovery-over by the ship against the longshoring employer:

In the event of injury to a person covered under this Act caused by the negligence of a vessel, then such person, or anyone otherwise entitled to recover damages by reason thereof, may bring an action against such vessel as a third party in accordance with the provisions of section 33 of this Act, and the employer shall not be liable to the vessel for such damages directly or indirectly and any agreements or warranties to the contrary shall be void. If such person was employed by the vessel to provide stevedoring services, no such action shall be permitted if the injury was caused by the negligence of persons engaged in providing stevedoring services to the vessel. If such person was employed by the vessel to provide ship building or repair services, no such action shall be permitted if the injury was caused by the negligence of persons engaged in providing ship building or repair services to the vessel. ${ }^{146}$

141. 350 U.S. at 132-35.

142. See 1972 Amendments, supra note 13.

143. 328 U.S. 85 (1946).

144. $I d$.

145. 1972 Amendments, supra note 13.

146. Id. 
It should be stressed that, despite the conspicuous place occupied by the Ryan line of cases in this field, the recovery-over problem after the demise of Ryan remains an important and active one both in federal cases other than those directly covered by the amendment, and in state cases. Since the sheer volume of reported cases related to Ryan was so great, they inevitably explored a rich assortment of detailed variations and permutations of the recovery-over problem, any of which may still arise under non-longshoreman federal law and under state law. It remains important, therefore, to analyze this body of precedent with some thoroughness. The discussion here is in three parts. The first deals with pre-1972 federal law, where some of these precedents may still have controlling force in non-longshoreman situations. The second deals with developments since the 1972 Amendments, a dominant theme of which is the effort of plaintiffs to find some way around the restrictions imposed by the amendments. The third concerns state law on contract-based implied indemnity, where Ryan will continue to have some influence, both because of the prestige of the Supreme Court, and because of the mass and variety of the body of case law it fathered.

\section{Pre-1972 Federal Law.}

\section{(n)}

(a) The Ryan Doctrine. The first major point established by Ryan was the decisive difference between recovery-over between parties whose relation rests ultimately on contract, and recovery-over between parties whose basic relation is noncontractual in origin. ${ }^{147}$ This distinction was felt to be indispensable both to avoid the exclusive-remedy provision of the Longshoremen's Act, and, in the process, to distinguish Halcyon Lines v. Haenn Ship Ceiling \& Refitting Corp. ${ }^{148}$ which had ruled out contribution in noncollision cases. ${ }^{149}$ The distinction was repeatedly reaffirmed by the Supreme Court ${ }^{150}$ and followed by the federal courts, ${ }^{151}$ and, although it did not escape criticism, ${ }^{152}$ it ap-

147. 350 U.S. at $130-32$.

148. 342 U.S. 282 (1952).

149. See text accompanying notes 22-26 supra.

150. Federal Marine Terminals, Inc. v. Burnside Shipping Co., 394 U.S. 404 (1969); Italia Societa per Azioni di Navigazione v. Oregon Stevedoring Co., 376 U.S. 315 (1964); Waterman S.S. Corp. v. Dugan \& McNamara, Inc., 364 U.S. 421 (1960); Crumady v. The Joachim Hendrik Fisser, 358 U.S. 423 (1959); Weyerhaeuser S.S. Co. v. Nacirema Operating Co., 355 U.S. 563 (1958).

151. Feliciano v. Compania Transatlantica Espanola S.A., 411 F.2d 976 (1st Cir. 1969); Murray v. United States, 405 F.2d 1361 (D.C. Cir. 1968); Ocean Drilling \& Exploration Co. v. Berry Bros. Oil Serv., 377 F.2d 511 (5th Cir.), cert. denied, 389 U.S. 849 (1967); Wien Alaska Airlines v. United States, 375 F.2d 736 (9th Cir.), cert. denied, 389 U.S. 940 (1967); United Air Lines v. 
peared to be about as firmly entrenched as any rule of law could be.

It must be stressed again that the contract-tort distinction in this connection goes to the roots of the parties' relation to each other, and not to the theory of the remedy sought. We have already dealt with the category in which the origin of the relation is noncontractual (e.g. a collision) and the form of the remedy is noncontractual (contribution between joint tortfeasors). We will later examine the category in which the origin of the relation is noncontractual but the remedy is described in contractual terms (e.g. indemnity). Ryan clearly could not be extended to this category. So far as the Ryan line of decisions is concerned, there is no such creature as "noncontractual indemnity." The Ryan category is contractual at both levels: there is some kind of contract in the background from which the rights and duties of the parties are ultimately derived, and the remedy is cast in contract-type terms, typically indemnity. The reason this is crucial in these cases is that the underlying contract is the rock on which is built the argument that the recovery in a case like Ryan is not on account of the injury, but rather on account of the contract.

(b) The "service aspect" of the Ryan Doctrine. The discussion up to this point has centered mainly on the rather negative point that a Ryan-type liability was not possible in the absence of a contractual base. But, of course, the fact that the relation between the third party and the employer was contractual did not in itself mean that every activity carried on in relation to the contract necessarily carried with it an implied obligation that would support an indemnity action. This point is well illustrated by the contrast between General Electric Co. $v$. Moretz ${ }^{153}$ and Halstead v. Norfolk \& Western Ry. ${ }^{154}$ In Moretz, the employee Moretz was a truck driver for Mason \& Dixon Lines. His truck overturned while transporting certain heavy equipment belonging to General Electric Company. He sued General Electric on the ground that the accident was due to its negligence in loading and insufficiently bracing the cargo. ${ }^{155}$ General Electric filed a third-party complaint against Mason \& Dixon contending that the accident was the

Wiener, 335 F.2d 379 (9th Cir.), cert. dismissed, 379 U.S. 951 (1964); General Elec. Co. v. Moretz, 270 F.2d 780 (4th Cir. 1959).

152. See Proudfoot, "The Tar Baby": Martime Personal-Injury Actions, 20 STAN. L. REv. 423 (1968). Proudfoot believes most of the complications and inequities following Ryan could have been avoided by handling the whole category of liability under tort principles.

153. 270 F.2d 780 (4th Cir. 1959), cert. denied, 361 U.S. 964 (1960).

154. 236 F. Supp. 182 (S.D. W. Va. 1964) (applying West Virginia law), affd, 350 F.2d 917 (4th Cir. 1965).

155. 270 F.2d at 782. 
fault of the carrier and demanding indemnity. ${ }^{156}$ The carrier was subject to the regulations of the Interstate Commerce Commission (ICC), one of which stated that "no motor vehicle shall be driven unless the driver thereof shall have satisfied himself that. . . all means of fastening the load are securely in place."157 Moretz reported to his employer that the load was not properly fastened, but the employer did nothing about it. The court read into the contract between the carrier and General Electric the ICC regulation, and held that under it the carrier assumed a direct and specific obligation to General Electric to secure the cargo properly. ${ }^{158}$ This obligation was found breached, and an obligation to indemnify General Electric arose.

In Halstead the relation between employer and third party was in a sense the reverse of that in Moretz. The employer in Halstead was engaged in unloading its own property from the railway when its employee was injured. The railway, having been sued by the employee, filed a third-party complaint against the employer, relying heavily on Moretz. ${ }^{159}$ It cited an ICC regulation placing the responsibility for unloading on the shipper. ${ }^{160}$ From this the railway tried to extract an implied duty to the railroad to perform the work in such a way as not to impose liability on the railway. The court distinguished Moretz in several ways, ${ }^{161}$ but principally on the ground that in Moretz the trucker was performing a service for the third party, along with which the duty of care ran. ${ }^{162}$ Here the employer was performing no service for the third party, but only for himself. "This 'service aspect," said the court, "is what the Ryan doctrine is founded on, and it was so emphasized in Crumady v. The Joachim Hendrick Fisser, 358 U.S. 423, 79 S. Ct. 445, 3 L.Ed.2d 413."163

The court relied on the decision in Hill Lines, Inc. v. Pittsburgh Plate Glass Co. ${ }^{164}$ in which the facts were substantially identical except that a truck line instead of a railway played the role of third party. The trucker asserted that the shipper-employer had a duty to unload the truck in a careful and prudent manner, and that this was an independ-

156. Id. at 782-83.

157. 49 C.F.R. 193.9(b) (1959).

158. $270 \mathrm{~F} .2 \mathrm{~d}$ at $787-89$.

159. 236 F.Supp. at 184 .

160. Id (quoting Unif. Freight Classification 5 , Rule 27, $\S 1$ ).

161. E.g., in Moretz there was not only an express jury finding that the employer's negligence was the proximate cause of the accident but also an express contractual obligation of the employer to secure the cargo. Neither of these facts had a counterpart in Halstead.

162. 236 F.Supp. at 186.

163. Id. at 187 .

164. 222 F.2d 854 (10th Cir. 1955) (decided under the New Mexico Workmen's Compensation Act). 
ent duty running to the trucker. The Tenth Circuit flatly rejected this theory.

The Halstead-Hill interpretation of Ryan means that, even if there is a contract between employer and third party, and even if this contract contains an implied obligation to perform certain functions with care because of incorporation by reference of ICC regulations or otherwise, this still does not generate a Ryan-type independent duty unless the functions being performed were a service to the third person under the contract. The analogy to a duty running with a manufacturer's sale of goods, invoked in the Ryan opinion itself, ${ }^{165}$ and again in Crumady, is clear, with services being substituted for goods. If no services are passing from the employer to the third person under the contract, the analogy breaks down.

(c) Scope of the Ryan Doctrine. The question whether the Ryan rule of implied indemnity was a limited maritime rule, or whether it was a principle of general applicability, remains an important one. Cases continue to arise on this issue under the 1972 Amendments, ${ }^{166}$ since if a principle of general applicability was established, a nonvessel may still be able to assert this kind of implied indemnity obligation against a stevedore. It might therefore, be useful to note here the cases on this point that arose before 1972 .

Perhaps the narrowest compass suggested for the doctrine was the precise fact situation under which Ryan arose, that is, the triangular relation under admiralty law of the stevedore, the longshoreman, and the shipowner. This was the position adopted by the Fifth Circuit. As Chief Judge John R. Brown colorfully expressed it in United States $v$. Seckinger: ${ }^{167}$

But the Government, as do all parties today, when everything else fails, falls back on the Tinker-to-Evers-to-Chance multiple impleaders in the Sieracki-Ryan-Yaka situations of indemnity based upon breach of the WWLP-the breach of the warranty of workmanlike performance. So far this court has kept this newly formed concept strictly confined to salt water or at least amphibious applications.

Seckinger involved an accident on dry land at a marine depot. The employee of a contractor had obtained a judgment against the

165. 350 U.S. at 133-34.

166. See, e.g. Zapico v. Bucyrus-Erie Co. v. Atlantic Container Line, Ltd., 579 F.2d 714 (2d Cir. 1978); Hamilton v. Mesa Petroleum Co., 495 F.Supp. 718 (E.D.La. 1980); Travis v. International MultiFoods Corp., 464 F.Supp. 503 (W.D.N.Y. 1978).

167. United States v. Seckinger, 408 F.2d 146, 153 (5th Cir. 1969), rev'd, 397 U.S. 203 (1970) (reversed on indemnity issue). 
United States for injuries incurred when he came in contact with a high voltage wire which, due to the government's negligence, had not been de-energized. The government then sued the contractor under an express contract of indemnification. The main point of the case was the familiar one that an express contract of indemnification will not be construed to cover the indemnitee's own negligence unless this is specifically stated in contract. 168 But, as Judge Brown indicated, as a last resort the government had fallen back on the implied indemnity theory of Ryan. The court not only refused to extend Ryan to nonmaritime cases, but added that "the express indemnity agreement may have waived any possible implied one."169 The Fifth Circuit's rule limiting Ryan essentially to its own fact situation dates from Halliburton Co. $v$. Norton Drilling Co. ${ }^{170}$ which refused to apply Ryan even in a case controlled by federal maritime law, but not presenting the stevedore-longshoreman-shipowner pattern. The locus of the injury was on a drilling barge in navigable waters, but the cast of characters consisted of an oil company, a drilling company, and an oil well servicing concern. The court concluded that, to the extent the Ryan line of cases permitted indemnification even when the indemnitee was to some degree negligent, this rule should be limited to stevedore-shipowner situations. ${ }^{171}$ It accounted for the exceptional rule in stevedoring cases by the fact that when a ship enters port the stevedore must know that it may have been battered by its sea trip and therefore full of hazards. ${ }^{172}$ In $\mathrm{Cen}$ traal Stikstof Verkoopkanter, N. v. Walsh Stevedoring Co. ${ }^{173}$ the Fifth Circuit reaffirmed its position, saying that "[t]he implied warranty established in Ryan is a product of the admiralty courts and a creature of admiralty law. . . . Those cases in which the doctrine has been applied have been admiralty cases which presented substantially similar circumstances to those existing in Ryan." 174 In the same year, the same court refused to apply the Ryan line of cases in a maritime situation involving repair work on a fixed, unmanned platform in the Gulf of

168. The case was reversed by the Supreme Court on the indemnity issue. 397 U.S. 203, 21927 (1970).

169. 408 F.2d at 153 n.18 (quoting Koninklyke v. Strachan Shipping Co., 301 F.2d 741, 746 (5th Cir. 1962)).

170. 302 F.2d 431 (5th Cir. 1962), cert denied, 374 U.S. 829 (1963). See also Delta Eng'r Corp. v. Scoth, 322 F.2d 11 (5th Cir. 1963), cert. denied, 377 U.S. 905 (1964).

171. 302 F.2d at 435 .

172. See id. at 436-37. The court cites a long, vivid passage on the perils of the sea and the consequent possible ragged condition of a newly-arrived ship from the opinion of Judge Mathes in Huger v. Dampskisaktieselskabet Int'1, 170 F.Supp. 601, $609-10$ (S.D. Cal. 1959), aff d sub nom. Metropolitan Stevedore Co. v. Dampskisaktieselskabet Int'l, 274 F.2d 875 (9th Cir. 1960).

173. 380 F.2d 523 (5th Cir. 1967).

174. Id. at 529 . 
Mexico. ${ }^{175}$ If the Fifth Circuit is, in these cases, trying to say that the central principle of the Ryan case itself cannot be extrapolated beyond stevedoring situations, the attempted limitation is debatable. But if what is meant is that some of the applications of Ryan to particular combinations of relative fault between stevedore and shipowner have no counterpart in cases not involving shipowners, the position is more defensible.

The central principle of Ryan, that there may be an implied obligation to use care in a service contract accompanied by an implied agreement of indemnity for breach of that obligation, has by no means been confined to maritime or shipowner cases, and has been applied in both state ${ }^{176}$ and federal ${ }^{177}$ courts in a variety of situations.

It is also a mistake to confine Ryan, as was essayed in Florida Power Light Co. v. Hercules Concrete Pile Co., ${ }^{178}$ to cases in which the indemnitee has been held liable without fault. The court there concluded, "It therefore appears that if the Ryan doctrine is extended, it would be extended only in favor of an indemnitee who has been liable without fault, based on some concept of strict liability such as unseaworthiness."179 The quickest way to expose the fallacy of limiting Ryan to cases in which the indemnitee has been held liable without

175. Ocean Drilling \& Exploration Co. v. Berry Bros. Oilfeld Serv., 377 F.2d 511 (5th Cir.), cert. denied, 389 U.S. 849 (1967). The court quotes the Supreme Court's language in Italia, 376 U.S. 315 (1964), to support isolation of Ryan:

But we deal here with a suit for indemnification based upon a maritime contract, governed by federal law ... ., in an area where rather special rules governing the obligations and liability of shipowners prevail, rules that are designed to minimize the hazards encountered by seamen, to compensate seamen for the accidents that inevitably occur, and to minimize the likelihood of such accidents.

377 F.2d at 513 (quoting Italia, 376 U.S. at 324). Note, however, that these "rather special" rules are concerned not with stevedoring companies but with seamen, and, of course, with longshoremen under the Sieracki rule holding that the liability of a shipowner for unseaworthiness extends to longshoremen. The only special feature, then, of Ryan-type fact situations is that the shipowner may become liable to the longshoreman without fault under the seaworthiness doctrine. Fact situations may therefore arise in which, as in Italia, the employer can become liable with very little fault because the shipowner has become liable with no fault. But fact situations may also arise-and these are much more common-in which the shipowner was guilty of some degree of negligence and would have been liable to the plaintiff longshoremen even if the special seaworthiness liability did not exist. The Ryan rule clearly applies to such cases, and, this being so, there is no reason why the Ryan cases should not be carried over to nonshipowner situations when the actual relation between the fault of the employer and third party is the same in principle.

176. See Blockford v. Sioux City Dressed Pork, Inc., 254 lowa 845, 118 N.W.2d 559 (1962); Whittenberg Eng'g \& Constr. Co. v. Liberty Mut. Ins. Co., 390 S.W.2d 877 (Ky. Ct. App. 1965); United States Fidelity \& Guar. Co. v. Kaiser Gypsum Co., 273 Or. 162, 539 P.2d 1065 (1975); Pan American Petroleum Corp. v. Maddux Well Serv., 586 P.2d 1220 (Wyo. 1978).

177. See, e.g., General Elec. Co. v. Moretz, 270 F.2d 780 (4th Cir. 1959), cert. denied, 361 U.S. 964 (1960); see text accompanying notes 153-58 supra for a discussion of the case.

178. 275 F. Supp. 427, 430 (S.D. Fla. 1967).

179. $I d$. 
fault is to adduce Weyerhaeuser Steamship Co. v. Nacirema Operating Co. ${ }^{180}$ in which the shipowner was indeed found by the jury to have been negligent, and in which his liability to the longshoreman had in fact been based on negligence and not on unseaworthiness-and in which the shipowner nevertheless recovered indemnity under Ryan. ${ }^{181}$ Indeed, the jury actually found that the ship was not unseaworthy as the result of the shipowner's negligence. ${ }^{182}$ The case is thus clear authority for the proposition that there may be indemnity on the part of the employer stevedore for an injury resulting from the concurring negligence of employer and shipowner.

In summary, it appears the sounder view to reject both of the pre1972 efforts to limit Ryan, one on the basis of a factual limitation to salt water, shipowners and stevedores, and the other on the basis of a conceptual limitation to strict liability in the indemnitee.

\section{Developments Since the 1972 Longshoremen's Act Amendments.}

(a) Attempts to evade the recovery-over restriction. The abolition of recovery-over by the ship against the stevedore was not accepted without a struggle by the members of the admiralty and personal injury bars. The chink through which the reintroduction of such recoveryover was attempted was the failure of Congress to address in explicit language the case of concurrent negligence by the ship and the stevedore. The argument runs like this: the amendment deals only with injury "caused by the negligence of a vessel," and says that the employer shall not be liable to the vessel "for such damages directly or indirectly"; 183 however, the argument continues, the recovery-over claim is not for "such damages," i.e., damages caused by the ship's negligence, but for damages caused by the stevedore's concurring negligence. ${ }^{184}$

Ingenious as this argument is, it encounters two formidable roadblocks. The first is the legislative history of the amendment, which sup-

180. 355 U.S. 563 (1958).

181. Id. at 567.

182. Id. at 564 .

183. See 1972 Amendments, supra note 13. See text accompanying note 146 supra.

184. This argument does not hold up well under scrutiny. As a matter of elementary tort law, the negligent ship is liable to the plaintif longshoreman for all the damages he has suffered, even if another tortfeasor might have contributed to the result by his concurrent negligence. If this were not so, how would it happen that the shipowner finds himself in fact liable to the plaintiff for the total damages? In the legal sense, then, the injury caused by the vessel's negligence with its resulting damages are indivisible at the moment the statute takes hold. "Such damages" can only mean the damages for which the ship has at that point been held liable--that is, the total damages. And for "such damages" the employer is expressly made not liable. 
ports the conclusion that Congress intended to eliminate recovery-over against the stevedore altogether. ${ }^{185}$ The second is that, even if the argument is correct, the net result is merely that the situation has been restored to what it was before Ryan-that is, that such recovery-over is barred by the basic rule that contribution between joint tortfeasors is ruled out by the exclusive remedy clause. ${ }^{186}$

The first post-amendment case to deal with this issue, Lucas $v$. "Brinknes" Schiffahrts Ges. Franz Lange G.N.B.H. \& Co. K.G. ${ }^{187}$ concluded that all recovery-over actions by the ship against the stevedore were barred after the amendment. 188 The injured longshoreman had collected workmen's compensation from the stevedore, and then sued the owner of the vessel, alleging negligence, since the unseaworthiness action had been abolished. ${ }^{189}$ The shipowner, in turn, fired a shotgun blast of possible claims against the stevedore, including every known variety of complete or partial reimbursement: ${ }^{190}$ indemnity, full or partial, for the damages awarded-a somewhat futile gesture in view of the amendment; a fifty percent credit or reduction of any damages-evidently an attempt to invoke the District of Columbia Murray Rule; ${ }^{191}$ contribution for a proportionate share of any damages, inspired no doubt by the New York case of Dole; ${ }^{192}$ and contribution or indemnity in the amount of workmen's compensation benefits paid or payable, reminiscent of the "Pennsylvania rule." 193

A three-judge panel, specially convened to handle the large volume of similar cases pending in the Eastern District of Pennsylvania, granted the stevedore's motion to dismiss all of these complaints for failure to state a cause of action. ${ }^{194}$ The main rationale of the court's decision was largely the first of the two roadblocks mentioned earlier, the congressional intent to abolish all recoveries-over by the shipowner against the stevedore. The court undertook an extensive examination of the legislative history behind the 1972 Amendments, and reached the conclusion that this history revealed an "[o]verriding concern to insulate the employer. . ." from any liability other than compensation lia-

185. See S. ReP. No. 1125, 92d Cong., 2d Sess. 4-5 (1972); H. R. REP. No. 1441, 92d Cong., 2d Sess. 4-8 (1972).

186. See cases cited at note 17 supra.

187. 1974 A.M.C. 1085 (E.D. Pa. 1974).

188. Id. at 1099.

189. Id. at 1095.

190. Id. at 1086-87.

191. See text accompanying notes 49-52 supra.

192. 30 N.Y.2d 143, 282 N.E.2d 288, 331 N.Y.S.2d 382 (1972).

193. See text accompanying notes 27-31 supra.

194. 1974 A.M.C. at 1087. 
bility. ${ }^{195}$ The court noted the balancing of interests of all parties that went into the amendment, with the shipowner receiving immunity from indemnity actions. The court said, referring to the amendment:

It specifically provided that the employer could not be held liable to the vessel by means of indemnity or hold harmless agreements. These prohibitions could only relate to attempts by the vessel to shift its negligence liability to the employer, for it is only for negligence that the vessel can be held liable. ${ }^{196}$

At another point, the court observes:

Congress sought to eliminate all actions against the stevedore whether for indemnity or contribution, whether based on tort or on contract, and whether for fees and expenses. Allowance of all such actions, even a pro tanto recovery to the extent of payments made by the employer under the Act, would create the circuitous type action Congress considered was too costly and disruptive of the compensation scheme to be permitted. ${ }^{197}$

The principal line of argument against this conclusion relies on the almost complete absence, ${ }^{198}$ both in the language of the amendment and in the legislative history, of any express treatment of the problem of concurrent negligence, as distinguished from the problem of unseaworthiness liability followed by an indemnity action. Too much signifcance, however, should not be attached to this omission. The problem before Congress, after all, was not one of concurrent negligence; it was the flood of cases released by Sieracki and Ryan. It was obviously as-

\footnotetext{
195. Id. at 1098.

196. Id. at 1099.

197. Id. at 1100 .
}

198. There was one significant colloquy suggesting that the subject was not completely overlooked. David B. Kaplan, Chairman of the Admiralty Section of the American Trial Lawyers Association, submitted a prepared statement discussing the possibility of proration of damages between the shipowner and the stevedore on the basis of their relative fault. Proposed Amendments to the Longshoremen's and Harbor Workers' Compensation Act: Hearings on S. 2318, S. 1547 Before the Subcomm. on Labor of the Senate Comm. on Labor and Public Welfare, 92nd Cong., 2d Sess. 355 (1972). In response to Mr. Kaplan's oral testimony supporting such a comparative negligence approach, Senator Eagleton stated:

Are you not really debating with us the legitimacy or illegitimacy of the concept of workmen's compensation and then I will add to that, was not that debate had in this country in the twenties, late twenties and thirties, when compensation was first coming into vogue in various States; that is, it was hotly debated, as I read about it?

Many trial lawyers back in that era bitterly opposed it. They strongly lobbied at the State level, to seeing that workmen's compensation not be enacted in [sic] various States.

Whether rightly or wrongly, have we not crossed that bridge? And we now have workmen's compensation; and once you have workmen's compensation, you have it?

Id. at 355. Making allowances for the convoluted and syntactically imperfect character of this excerpt, one can discern a tacit congressional assumption that the inappropriateness of any such comparative negligence liability on the part of the employer was well settled as part of the intrinsic tradition of workmen's compensation. 
sumed by Congress that, under existing cases on contribution, ${ }^{199}$ no recovery-over against a concurrently negligent stevedore was possible, and that therefore no special mention of that kind of liability was necessary to confirm that it was barred. The Ryan opinion itself had been at some pains to stress the distinction between contribution and indemnity, 200 to clear the way for the allowance of an indemnity recovery in spite of the assumed unavailability of contribution.

In any event, the language of the statute is by no means literally confined to indemnity. Although it does not expressly speak of contribution in concurring negligence cases, the general language is broad enough to cover any such claim. It states in unqualified terms: "the employer shall not be liable to the vessel for such damages directly or indirectly." 201 This language plainly covers liability in the form of contribution or any other kind of sharing of the damages, whether by indemnity or otherwise. The passage then goes on to state: "and any agreement and warranties of the contrary shall be void." 202 This introduces the Ryan-type of liability, but only as an addendum to the unlimited bar just preceding this clause. It is grammatically and logically impossible to read the entire passage as being somehow confined to the area referred to in the addendum, that of warranties giving rise to indemnity claims.

Since the failure of the recovery-over attempt in Lucas, and in one or two other district court cases, ${ }^{203}$ the attempt to break down the amendment's almost impregnable barrier against such recoveries appears to have been largely abandoned. But one of the other devices tried in Lucas, the earlier Pennsylvania-type compromise, generated several more years of controversy, until put to rest by the Supreme Court in 1979 in Edwards v. Compagnie Generale Transatlantique.204 In Edmonds, a longshoreman, employed by a stevedoring company, was injured while working aboard a ship. The longshoreman brought a tort suit alleging negligence by the shipowner. A jury found that the stevedoring company's negligence contributed $70 \%$ of the fault, the ship's $20 \%$, and the longshoreman's $10 \% .{ }^{205}$ On rehearing, sitting en banc, the

199. See, e.g., Pope \& Talbot, Inc. v. Hawn, 346 U.S. 406 (1953); Halcyon Lines v. Haenn Ship Ceiling \& Refiting Corp., 342 U.S. 282 (1952); Murray v. United States, 405 F.2d 1361 (D.C. Cir. 1968).

200. See text accompanying notes 150-53 supra.

201. 33 U.S.C. $\S 905(b)(1976)$. See text accompanying note 147 supra.

202. $I d$.

203. See Swans v. United States Lines, Inc., 407 F. Supp. 388, 393-94 (E.D. Pa. 1975); Landon

v. Lief Hoegh \& Co., 386 F. Supp. 1081, 1084 (E.D.N.Y. 1974).

204. 443 U.S. 256 (1979).

205. Id. at 258. 
Court of Appeals for the Fourth Circuit adopted a comparative negligence standard and held that the shipowner could be required to pay only that proportion of the total damages which matched its proportion of fault. ${ }^{206}$ The court noted that its decision conflicted with decisions in the Fifth ${ }^{207}$ and Ninth ${ }^{208}$ Circuits. The Supreme Court reversed, holding that the 1972 Amendments were not intended to change the judgemade rule that the shipowner was liable for all damages not due to the employee's fault, including damages due to the employer's negligence. ${ }^{209}$ The Court was sensitive to the equitable arguments for undertaking some kind of apportionment. But the plain language of the amendment left no room for such considerations: "the employer shall not be liable to the vessel for such damages directly or indirectly."210 The apportionment undertaken below clearly had the effect of making the employer liable indirectly. This being the rationale of the decision it is obviously no less applicable in cases in which the employer has intervened and prosecuted the case. ${ }^{211}$

(b) Attempts to broaden the grounds for liability of the ship. The 1972 amendments were intended to break the Ryan cycle at two points. The one break was at the point of the recovery-over by the vessel against the employer; as we have just seen, efforts to thwart this break have failed completely. The other break was at the point of the employee's recovery from the vessel for unseaworthiness, leaving intact, however, his action for "negligence." Here the plaintiffs' efforts have taken the form of trying to maximize the grounds for the vessel's liability, if possible, stretching them to include some kind of strict liability other than unseaworthiness. An enormous volume of litigation and reported case law has developed, but here again the Supreme Court went a long way toward clearing the decks, with its 1981 opinion in Scindia Steam Navigation Co. v. Santos. ${ }^{212}$ Santos was a longshoreman unloading cargo when sacks of wheat fell on him from a pallet overhead. The winch used in unloading the wheat had a brake mechanism which had malfunctioned on the day of the accident as well as on the previous two days. ${ }^{213}$ The Court considered the negligence standards under sec-

206. 577 F.2d 1153, 1155 (4th Cir. 1978).

207. See Samuels v. Empresa Lineas Maritimas Argentinas, 573 F.2d 884, 888-39 (5th Cir. 1978), cert. denied, 443 U.S. 915 (1979).

208. See Shellman v. United States Lines, Inc., 528 F.2d 675, 680-81 (9th Cir. 1975), cert. denied, 425 U.S. 936 (1976).

209. 443 U.S. at 266.

210. Id. at 265-66.

211. See McCormack v. Noble Drilling Corp., 608 F.2d 169, 175 (5th Cir. 1979).

212. 451 U.S. 156 (1981).

213. Id. at 160 . 
tion $5(b)^{214}$ suits against the shipowner. The district court had applied the RESTATEMENT (SECOND) OF TORTs land-based rules for invitees: the shipowner was not liable for dangerous conditions caused by the stevedore's negligence while the stevedore was in exclusive control of the work, since the shipowner could not have known of the dangerous condition. ${ }^{215}$ Nor was he under a duty to warn the stevedore of open or obvious dangers and defects. ${ }^{216}$ The Court of Appeals for the Ninth Circuit reversed a summary judgment for Scindia. ${ }^{217}$ It rejected the land-based Restatement standards as incorporating such notions as contributory negligence and assumption of risk. ${ }^{218}$ It held the shipowner liable if the owner was aware of an unreasonable risk to the longshoremen and failed to use reasonable care to protect them. ${ }^{219}$ It also held that Scindia had a duty to inspect even after turning over the ship in safe condition to the stevedore. 220 The Supreme Court disagreed with both courts. ${ }^{221}$ The Court first reiterated its holding in Marine Terminals v. Burnside Shipping Co.:222 the shipowner had a duty to exercise reasonable care and warn the stevedore of defects known to him that would not be obvious to the stevedore.223 But the shipowner need not have supervised the stevedoring operation.

Absent contract provision, positive law or custom to the contrary . . . the shipowner has no general duty by way of supervision or inspection to exercise reasonable care to discover dangerous conditions that develop within the confines of the cargo operations that are assigned to the stevedore. . . . [T] men for injuries caused by dangers unknown to the owner and about which he had no duty to inform himself. 224

However, the shipowner may have a duty to intervene when a dangerous condition exists in the cargo operation, such as the malfunctioning winch, which is known by the stevedore and dangerous to longshoremen. ${ }^{225}$ The Court thought it possible that the stevedore's "judgment in this respect was so obviously improvident that Scindia, if it knew of the defect and that [the stevedore] was continuing to use it, should have

214. 33 U.S.C. 905 (b) (1976).

215. Santos v. Scindia Steam Navigation Co., 1976 A.M.C. 2583, 2586 (W.D. Wash. 1976), (citing Restatement (SECOND) OF TORTS $\$ \$ 343-343 A$ (1965)).

216. See Restatement (SECOND) OF TORTs, § 343-343A (1965).

217. 598 F.2d 480, 491 (9th Cir. 1979).

218. Id. at 486 .

219. Id. at 489 .

220. $I d$.

221. 451 U.S. at $168,174-75$.

222. 394 U.S. 404 (1969).

223. Id. at 418 .

224. $I d$.

225. Jd. at $415-17 \mathrm{nn} .17 \& 18$. 
realized the winch presented an unreasonable risk of harm to the longshoremen, and that in such circumstance it had a duty to intervene and repair the ship's winch. The same would be true if the defect existed from the outset and Scindia must be deemed to have been aware of the condition." 226 The Court then said an inquiry into safety statutes, regulations, and customs was necessary to determine whether the ship had a duty to repair the winch.227 The case was remanded to discover whether the shipowner had actual knowledge or was chargeable with knowledge of the defective winch. ${ }^{228}$

While Scindia may not have dealt specifically with the many details presented by these cases, the great bulk of the questions can be answered by considering them against the broad principles the Court announced as well as against those the Court rejected.229

(c) Effect of 1972 Amendments on nonvessel third parties. The abolition by the 1972 Amendments of recovery-over against the employer was expressly limited to such actions brought by vessels. This has given rise to three questions on the impact of this change on nonvessels, two of which are rather one-sided, and the third of which is more troublesome.

The first question is whether the amendments in any way altered the well-established rule banning recovery-over in the form of contribution. The courts have consistently held that there is nothing in the amendments indicating that any such change was intended. ${ }^{230}$ The second question is whether the provision that "any agreements and warranties to the contrary shall be void"231 — which plainly includes express warranties-invalidates express indemnity agreements between the employer and a nonvessel third party. Again, the courts consistently hold that, under the clear language of the statute, an agreement with a nonvessel third party is not affected. ${ }^{232}$

Somewhat closer is the third question: whether, after the amendments, the nonvessel third party can assert against the employer a Ryan-style implied warranty of workmanlike performance. Most

226. 451 U.S. 175-76 (footnote omitted).

227. Id.

228. Id. at 175-76.

229. For a detailed examination of pre-Scindia cases, some of which are clearly discredited, others of which may have minor value as to details, see A. LARSON, WORKMEN's CoMpENSATION, $\S 76.63$ (c) n.23 (1982).

230. See, e.g., Zapico v. Bucyrus-Erie Co., 579 F.2d 714, 719 (2d Cir. 1978).

231. Longshoremen's and Harbor Workers' Compensation Act, 33 U.S.C. $§ 905$ (b) (1976).

232. E.g., Olsen v. Shell Oil Co., 595 F.2d 1099, 1103 (5th Cir.), cert. denied., 444 U.S. 979 (1979). 
courts, ${ }^{233}$ but not all, ${ }^{234}$ have refused to recognize such an implied warranty. It was noted earlier that, long before the 1972 Amendments, a number of courts had struggled with the question whether the Ryan principle was confined to the vessel-stevedore relation, or whether it was of general applicability. The analysis at that point concluded that the preponderance of authority supported the latter view. ${ }^{235}$ The arguments in the post-1972 cases are largely a reprise of the earlier arguments. ${ }^{236}$ In one respect the amendments have weakened the case for indemnity, by undermining the third-party beneficiary argument. In several of the unsuccessful post-1972 cases, the nonvessel third party argued that he was the third-party beneficiary of an implied warranty running from the stevedore to the ship. ${ }^{237}$ In each case, the argument was rejected on the ground that the 1972 Amendments had destroyed that underlying warranty itself. ${ }^{238}$ They did not merely block the vessel's remedy; they declared the warranty void, so that no one, vessel or nonvessel, could extract any remedy from it. The successful case of Gould v. General Mills, Inc. ${ }^{239}$ stands out from the others by reason of the extent to which it relied on totally independent duties running, not from the stevedore to the vessel, but from the stevedore to the nonvessel third party, such as the duty to provide qualified personnel. ${ }^{240} \mathrm{An}$ other post-1972 argument against implied indemnity has also perhaps more force after the total experience of the Ryan story than before. This is the contention that there was a sort of reciprocity between the Ryan implied warranty and the Sieracki unseaworthiness liability. That is, the unseaworthiness liability cast such a heavy burden on the ship-as became increasingly evident in the years leading up to 1972-

233. See, e.g., Zapico v. Bucyrus-Erie Co., 579 F.2d 714 (2d Cir. 1978); Hamilton v. Mesa Petroleum Co., 495 F. Supp. 718, 720-22 (E.D. La. 1980); Travis v. International Multifoods Corp., 464 F. Supp. 503, 507-08 (W.D.N.Y. 1978); Kane v. Firestone Steel Prods. Co., 463 F. Supp. 473 (E.D. Pa. 1978); Spadola v. Viking Yacht Co., 441 F. Supp. 798, 800-03 (S.D.N.Y. 1977); S.S. Seatrain La. v. California Stevedore \& Ballast Co., 424 F. Supp. 180, 183-84 (N.D. Cal. 1976); Fitzgerald v. Compania Naviera La Molinera, 394 F. Supp. 402, 408 (E.D. La. 1974). See also McCune v. F. Alioto Fish Co., 597 F.2d 1244, 1251 (9th Cir. 1979) (recognizing that the Ryan implied warranty had been extended to non-stevedoring cases, the court declined to extend it to the manufacture of products).

234. See, e.g., Gould v. General Mills, Inc., 411 F. Supp. 1181, 1184 (W.D.N.Y. 1976).

235. See text accompanying notes $166-82$ supra.

236. See, eg., Hamilton v. Mesa Petroleum Co., 495 F. Supp. 718 (E.D. La. 1980), relying directly on Ocean Drilling \& Exploration Co. v. Berry Bros. Oilfeld Serv., 377 F.2d 511 (5th Cir.), cert. denied, 389 U.S. 849 (1967) (a pre-1972 case).

237. See Zapico v. Bucyrus-Erie Co., 579 F.2d 714, 719 (2d Cir. 1978); Travis v. International Multifoods Corp., 464 F. Supp. 503, 507-08 (W.D.N.Y. 1978); S.S. Seatrain Louisiana v. California Stevedore \& Ballast Co., 424 F. Supp. 180, 183-84 (N.D. Cal. 1976).

238. $I d$.

239. 411 F. Supp. 1181 (W.D.N.Y. 1976).

240. See id. at 1184 . 
that the implied warranty rule was devised to help the ship shift some of that burden to the stevedore. It follows, so the argument runs, that there was no comparable justification for providing the implied-warranty type of relief to others than shipowners. ${ }^{241}$ There is a second argument against indemnity made possible by the amendments. It could be urged that Congress, in these amendments, was giving expression to a broad public policy disfavoring the kind of litigation-fomenting spiral associated with Ryan, 242 and that accordingly the sweep of the amendments should not be too literally restricted to the four corners of the statutory language. The Second Circuit, in Zapico v. Bucyrus-Erie Co. ${ }^{243}$ declined to adopt this rationale, relying instead on the simple absence of an independent duty of care running from the user of a negligently manufactured product to the manufacturer. ${ }^{244}$ As we shall see, this approach has had more success when the issue was that of extending the impact of the amendments to the Federal Employees' Compensation Act.

(d). Effect of 1972 Amendments on FECA liabilities. The first circuit to deal with the question whether the impact of the 1972 Amendments should be extended to the Federal Employees' Compensation Act (FECA) was the Fifth Circuit, in Aparicio v. Swan Lake.245 Harbor workers employed by the Panama Canal Company filed unseaworthiness and negligence claims against vessels on which they were injured. The ships in turn alleged a Sieracki-Ryan breach of warranty of workmanlike performance against the employer. 246 The Panama Canal Company asserted as a defense to the warranty claim immunity based on the 1972 Amendments to the LHWCA. The court held that such a defense was not available to the Company because its workers were covered by the FECA and not by the LHWCA. ${ }^{247}$ There was no intent, either in section 5(b) or in the legislative history, "to liberate from Sieracki vessel owners and stevedores not subject to LHWCA liability."248 Unaware of what the Fifth Circuit had decided five days earlier in Aparicio, the Ninth Circuit reached the opposite result in Nor-

241. See S.S. Seatrain Louisiana v. California Stevedore \& Ballast Co., 424 F. Supp. 180 (N.D. Cal. 1976); Fitzgerald v. Compania Naviera La Molinera, 394 F. Supp. 402 (E.D. La. 1974), in which this rationale figured strongly.

242. See, e.g., Travis v. International Multifoods, 464 F. Supp. 503, 506 (W.D.N.Y. 1978).

243. 579 F.2d 714 (2d Cir. 1978).

244. Id. at 723 .

245. 643 F.2d 1109 (5th Cir. 1981).

246. $I d$. at 1110 .

247. $I d$. at 1118 .

248. Id. at 1116 . 
mile v. Maritime Co. ${ }^{249}$ It held that a federally-employed longshoreman had no unseaworthiness remedy. The court rejected the application of Sieracki to FECA-covered employees, although the 1972 Amendments overruling Sieracki applied only to that Act, and section $3(a)(2)$ of the LHWCA specifically exempted federal employees from its coverage. 250 The court postulated that, although the LHWCA amendments "eviscerated if not eliminated Sieracki," 251 Congress addressed only the most obvious cases and left it to the courts "to interweave the new legislative policies with the inherited body of commonlaw principles."252 The court did not explain why Congress would not have amended the FECA if it had wanted the 1972 Amendments to affect both acts. Nor did the court explain why it noted as remedies available to Normile both compensation under the FECA and negligence recovery under section 5(b) after it recognized the restrictions of Section 3(a)(2). ${ }^{253}$

\section{B. Implied Contractual Indemnity under State Law.}

When we turn to cases arising under state law, we find a sharp divergence of opinion between the minority of jursidictions which hold that, when the relation between the parties is based on contract, an obligation of care with accompanying indemnity obligation can be implied which survives the exclusiveness defense, ${ }^{254}$ and the majority that reject the implied indemnity doctrine. 255

249. 643 F.2d 1380 (9th Cir. 1981).

250. Id.

251. Id. at 1382 .

252. Id. at $1382 \mathrm{n} .3$ (citations omitted).

253. Id. at 1382 n.2.

254. See, e.g. Harn v. Standard Eng'g Co., 416 F.Supp. $116^{\circ}$ (D. S.D. 1976) (applying South Dakota law); Blackford v. Sioux City Dressed Pork, Inc., 254 Iowa 845, 118 N.W.2d 559 (1962); Whittenberg Eng'g \& Constr. Co. v. Liberty Mut. Ins. Co., 390 S.W.2d 877 (Ky. Ct. App. 1965); United States Fidelity \& Guar. Co. v. Kaiser Gypsum Co., 273 Or. 162, 539 P.2d 1065 (1975) (An employee of Kaiser lost his hand when testing a machine which had had its protective guard removed at Kaiser's request. The employee sued the insurer of the company that installed the machine and settled for $\$ 25,000$. Id. at 164, 539 P.2d at 1066. The insurer brought a third-party action against Kaiser seeking indemnity. The court held that Kaiser owed an independent duty to the installer to maintain the protective guard, and therefore could not defend the indemnity action on the basis of employer immunity under the Workmen's Compensation Act. Id. at 166-67, 539 P.2d at 1067); Pan Am. Petroleum Corp. v. Maddux Well Serv., 586 P.2d 1220 (Wyo. 1978).

255. See, e.g., Missouri Pub. Serv. Co. v. Henningsen Steel Prods. Co., 612 F.2d 363 (8th Cir. 1980) (applying Missouri law); Bjerk v. Universal Eng'g Corp., 552 F.2d 1314 (8th Cir. 1977) (applying Minnesota law); Kudelka v. American Hoist \& Derrick Co., 541 F.2d 651 (7th Cir. 1976) (applying the FECA); General Elec. Co. v. Cuban Am. Nickel Co., 396 F.2d 89 (5th Cir. 1968) (applying Louisiana law); Centraal Stikstof Verkoopkanter, N.V. v. Walsh Stevedoring Co., 380 F.2d 523 (5th Cir. 1967) (holding that the implied warranty in Ryan was a product of admiralty law and should not be extended to a case controlled by Alabama law); Bertone v. Turco 
A great part of the controversy between these cases has been supplied, not by the issue whether an independent duty to indemnify based on contract is free of the compensation exclusiveness principle, but by the issue whether under the law of the jurisdiction there is an implied obligation of care and indemnity in the circumstances. Because Ryan and related maritime cases bulked so large in this area, courts all too often approached the issue as if it were a matter of taking sides for or against Ryan; some would then emphasize the peculiarities of the stevedore-shipowner situation, and conclude that apart from such peculiarities Ryan should not be emulated.256 As we have seen, however, the doctrine here involved has some support in nonstevedore, nonmaritime, and nonfederal-law cases. The limiting factor is not the maritime quality but rather the underlying contractual quality of the relation. The key to this type of case is that some kind of service was performed for the indemnitee under contract, along which an implied obligation could run to the indemnitee to perform with due care, and to indemnify for damages flowing from breach of this obligation.

Probably the most troublesome point of difference is between those cases that permit indemnity when the indemnitee's fault is relatively minor and those that flatly rule out indemnity if the indemnitee is guilty of any fault at all. The issue is well illustrated by the Florida opinion in Florida Power \& Light Co. v. Hercules Concrete Pile Co. 257 The court quotes the following Supreme Court statement from the

Prods., Inc., 252 F.2d 726 (3d Cir. 1958) (applying New Jersey law) (finding no possibility of an implied agreement to indemnify arising out of the purchase of a solvent); Burrell v. Rodgers, 441 F. Supp. 275 (W.D. Okla. 1977) (applying Oklahoma law); Trammel v. Appalachian Elec. Coop., 135 F. Supp. 512 (E.D. Tenn. 1955); E.B. Wills Co. v. Superior Court, 56 Cal. App. 3d 650, 128 Cal. Rptr. 541 (1976); Hilzer v. MacDonald, 454 P.2d 928, 169 Col. 230 (1969); Central of Ga. Ry. v. Lester, 118 Ga. App. 794, 165 S.E.2d 587 (1968); American Radiator \& Standard Sanitary Corp. v. Mark Eng'g Co., 230 Md. 584, 187 A.2d 864 (1963); Diekevers v. Brekel Inc., 73 Mich. App. 78, 250 N.W.2d 548 (1976); Holly Sugar Corp. v. Union Supply Co., 194 Colo. 316, 572 P.2d 148 (1977) (applying Colorado and Montana law); Outboard Marine Corp. v. Schupbach, 93 Nev. 158, 561 P.2d 450 (1977); Ruvolo v. United States Steel Corp., 139 N.J. Super. 578, 354 A.2d 685 (N.J. Super. Ct. Law Div. 1976), modifying 133 N.J. Super. 362, 336 A.2d 508 (N.J. Super. Ct. Law. Div. 1975) (commenting on problem posed by fact that rule it applied would always result in complete victory for one or another of the two alleged tortfeasors, but declining, in light of New Jersey law, to succumb to "seductive reasoning" of Dole v. Dow Chem. Co., 30 N.Y.2d 143, 282 N.E.2d 288, 331 N.Y.S.2d 382 (1972) as way of achieving compromise); Royal Indem. Co. v. Southern Cal. Petroleum Corp., 67 N.M. 137, 353 P.2d 358 (1960); Sayler v. Holstrum, 239 N.W.2d 276 (N.D. 1976); Montoya v. Greenway Aluminum Co., 10 Wash. App. 630, 519 P.2d 22 (1974).

256. E.g., United States v. Seckinger, 408 F.2d 146, 153 (5th Cir. 1969); Centraal Stikstof Verkoopkanter v. Walsh Stevedoring Co., 380 F.2d 523, 529 (5th Cir. 1967); Ocean Drilling \& Exploration Co. v. Berry Bros. Oilfeld Serv., Inc., 377 F.2d 511, 513 (5th Cir.), cert. denied, 389 U.S. 849 (1967). See 2A LARSON, WoRKMEN's COMPENSATION $\$ 76.43$ (a) (1982).

257. 275 F. Supp. 427 (S.D. Fla. 1967). 
Italia ${ }^{258}$ opinion:

Where the shipowner is liable to the employees of the stevedoring company . . . for failing to supply a vessel and equipment free of defects, regardless of negligence, we do not think it unfair or unwise to require the stevedore to indemnify the shipowner for damages sustained as a result of injury-producing equipment supplied by the stevedore in furtherance of its contractual obligations. ${ }^{259}$

The district court perceived this as the "underlying basis for the Ryan doctrine." 260 If by this the court means, as its italics indicate, that the essence of the Ryan doctrine is that the indemnitee in a Ryan recovery must be free from negligence, the statement is demonstrably wrong. Weyerhaeuser had already established beyond all doubt that a shipowner could be guilty of some negligence and still recover under Ryan, ${ }^{261}$ and the question from that point on became: how much negligence? Nevertheless, the court goes on:

It therefore appears that if the Ryan doctrine is extended, it would be extended only in favor of an indemnitee who has been held liable without fault, based on some concept of strict liability such as unseaworthiness. However, here as in the Ocean Drilling case, the plaintiff's liability to Rita Ahearn could not have been based on liability without fault. On the contrary, as plaintiff points out, its liability was based on its own negligence, even though it chooses to characterize that negligence as "passive." 262

What is really at stake here is the distinction between an indemnitee who has become liable without fault in any real sense, and an indemnitee who has become liable on the basis of a degree of fault that is relatively much less than that of the indemnitor. Practically all authorities, including texts and restatements, would agree that, if the indemnitee has become liable on purely technical or vicarious grounds, his constructive "fault" should not bar his right of indemnity against one who has saddled him with liability through genuinely tortious conduct. ${ }^{263}$ This would include an indemnitee made liable, for example, solely by an automobile owner's liability statute, ${ }^{264}$ or by a nondelegable duty with respect to the coridition of premises. ${ }^{265}$ Difficulty arises when the fault of the indemnitee moves from "constructive" or "technical" to "passive" or "secondary." It is submitted that much of the diffi-

258. Italia Societa per Azioni di Navigazione v. Oregon Stevedoring, 376 U.S. 315 (1964).

259. 275 F.Supp. at 430, citing Italia, 376 U.S. at 324 (emphasis added).

260. 275 F.Supp. at 430.

261. See Weyerhaeuser S.S. Co. v. Nacirema Operating Co., 372 U.S. 597, 602 (1963).

262. 275 F.Supp at 430.

263. See Prosser, Torts $\$ 51$ at 311 (4th ed. 1971); Restatement of Restitution $\S \S 76,95$ (1937).

264. See text accompanying notes $124-26$ supra.

265. Restatement OF Restitution $\S 95$, Comment $a$ (1937). 
culty can be avoided by eschewing the use of vague adjectival descriptions like "passive" and sticking to the familiar factual interplay between creation of a danger and failure to discover it. It is difficult to see why there should be any insuperable conceptual obstacle to saying that when the employer negligently creates a dangerous condition in performing a service for the third party, he should indemnify the third party even if the third party was negligent to the extent of failing to discover the danger. It must always be borne in mind that we are here talking about a contractual relation. This helps to expose the sharp difference between the two forms of default. It is relatively easy to say that one contracting to perform services agrees not to create dangerous conditions. It is much harder to say that one accepting and paying for such services agrees that he will discover any dangerous conditions created by the contractor.

\section{NonCONTRACTUAL INDEMNITY}

$U_{p}$ to this point, the genesis of the relation between the employer and the third party has been either a contract or a special relationship, such as that of bailee or bailor, that carries with it an established set of legal rights and duties. The final combination to be examined is that in which there is no contractual or special relation, the simplest illustration being that of a collision between strangers. If the form of the recovery-over by the third party against the employer sounds in tort, as in a claim for contribution, the near-universal case-law rule, as noted earlier, ${ }^{266}$ bars the action under the exclusive-remedy principle. There remains the question whether, by clothing his claim in the form of indemnity, the third party can surmount the exclusiveness barrier.

\section{A. Summary of Case Law.}

The third-party plaintiff here has not one hurdle but two to leap. He must first establish that the law implies an agreement by the primary tortfeasor to indemnify the secondary. But even if he can do this, the harder task remains: he must show that this liability, even if contractual in form, is not on account of the injury. The final result of this dual obstacle is clear: the great majority of cases hold that, when the relationship between the parties does not spring from a contract or special position such as bailee or lessee, the third party cannot recover indemnity from the employer. ${ }^{267}$ The usual reason is that an active or

266. See text accompanying notes 19-20 supra.

267. Santisteven v. Dow Chem. Co., 506 F.2d 1216 (9th Cir. 1974) (applying Nevada law); Kessler v. Bowie Mach. Works, 501 F.2d 617 (8th Cir. 1974); Smith Petroleum Serv. v. Monsanto 
primary wrongdoer does not have an implied obligation, capable of penetrating the exclusiveness rule of workmen's compensation law, to indemnify a passive or secondary wrongdoer. Several jurisdictions, however, have reached a contrary conclusion. ${ }^{268}$

In the leading case establishing the majority rule, ${ }^{269}$ Judge Learned Hand gave the following reason for the holding:

[W] shall assume that, when the indemnitor and indemnitee are. both liable to the injured person, it is the law of New Jersey that, regardless of any other relation between them, the difference in gravity of their faults may be great enough to throw the whole loss upon one. We cannot, however, agree that result is rationally possible except upon the assumption that both parties are liable to the same person for the joint wrong. If so, when one of the two is not so liable,

Chem. Co., 420 F.2d 1103 (5th Cir. 1970) (applying Mississippi law); General Elec. Co. v. Cuban Am. Nickel Co., 396 F.2d 89 (5th Cir. 1968) (applying Louisiana law); Ocean Drilling \& Exploration Co. v. Berry Bros. Oilfield Serv., 377 F.2d 511 (5th Cir.), cert. denied, 389 U.S. 849 (1967) (applying Louisiana law); United Air Lines, Inc. v. Wiener, 335 F.2d 379 (9th Cir.), cert. dismissed, 379 U.S. 951 (1964); Halliburton Co. v. Norton Drilling Co., 302 F.2d 431 (5th Cir. 1962); Bertone v. Turco Prod., Inc., 252 F.2d 726 (3d Cir. 1958) (applying New Jersey law); Crawford v. Pope \& Talbot, Inc., 206 F.2d 784 (3d Cir. 1953); American Mut. Liab. Ins. Co. v. Matthews, 182 F.2d 322 (2d Cir. 1950); Belcher v. J.H. Fletcher \& Co., 498 F. Supp. 629 (S.D. W. Va. 1980) (applying West Virginia law); Oman v. Johns-Manville Corp., 482 F. Supp. 1060 (E.D. Va. 1980), aff'd sub nom. White v. Johns-Manville Corp., 662 F.2d 243 (4th Cir. 1981) (applying Virginia law); Roy v. Star Chopper Co., 442 F. Supp. 1010 (D.R.I. 1977), affd, 584 F.2d 1124 (Ist Cir. 1978), cert. denied, 440 U.S. 916 (1979) (applying Massachusetts law); Ranta v. Bethlehem Steel Corp., 287 F. Supp. 111 (D. Conn. 1968) (applying Connecticut law); Howard v. Wilson Concrete Co., 57 F.R.D. 8 (W.D. Mo. 1972); Redwing Carriers, Inc. v. Crown Cent. Petroleum Corp., 356 So. 2d 1203 (Ala. 1978); Golden Valley Elec. Ass'n v. City Elec. Serv., 518 P.2d 65 (Alaska 1974); Desert Steel Co. v. Superior Court, 22 Ariz. App. 279, 526 P.2d 1077 (1974); Jack Morgan Constr. Co. v. Larkan, 254 Ark. 838, 496 S.W.2d 431 (1973); Hilzer v. MacDonald, 169 Colo. 230, 454 P.2d 928 (1969); Howard, Needles, Tammen \& Bergendoff v. Steers, Perini \& Pomeroy, 312 A.2d 621 (Del. 1973); Houdaille Indus. v. Edwards, 374 So. 2d 490 (Fla. 1979); Central of Ga. Ry. v. Lester, 118 Ga. App. 794, 165 S.E.2d 587 (1968); Iowa Power \& Light Co. v. Abild Constr. Co., 259 Iowa 314, 144 N.W.2d 303 (1966); McCleskey v. Noble Corp., 2 Kan. App. 2d 240, 577 P.2d 830 (1978); Roberts v. American Chain \& Cable Co., 259 A.2d 43 (Me. 1969); Outboard Marine Corp. v. Schubpach, 93 Nev. 158, 561 P.2d 450 (1977) (approving the interpretation of the Nevada act by the Federal courts in Santisteven); William H. Field Co. v. Nuroco Woodwork, Inc., 115 N.H. 632, 348 A.2d 716 (1975); Ruvolo v. United States Steel Corp., 139 N.J. Super. 578, 354 A.2d 685 (N.J. Super. Ct. Law Div. 1976); Hunsucker v. High Point Bending \& Chair Co., 237 N.C. 559, 75 S.E.2d 768 (1953); Sayler v. Holstrom, 239 N.W.2d 276 (N.D. 1976); Williams v. Ashland Chem. Corp., 52 Ohio App. 2d 81, 368 N.E.2d 304 (1976); Harter Concrete Prods., Inc. v. Harris, 592 P.2d 526 (Okla. 1979); Boldman v. Mt. Hood Chem. Corp., 288 Or. 121, 602 P.2d 1072 (1979); Rupe v. Durbin Durco, Inc., 557 S.W.2d 742 (Tenn. App. 1976); City of Abilene v. Jones, 355 S.W.2d 597 (Tex. Civ. App. 1962); Seattle-First Nat'l. Bank v. Shoreline Concrete Co., 91 Wash. 2d 230, 588 P.2d 1308 (1978); A.O. Smith Corp. v. Associated Sales \& Bag Co., 16 Wis. 2d 145, 113 N.W.2d 562 (1962); Mulder v. Acme-Cleveland Corp., 95 Wis.2d 173, 290 N.W.2d 276 (1980).

268. Miller v. De Witt, 37 Ill.2d 273, 226 N.E.2d 630 (1967); Ashland Oil \& Refining Co. v. General Tel. Co., 462 S.W.2d 190 (Ky. 1970); Dale v. Whiteman, 388 Mich. 698, 202 N.W.2d 797 (1972); Westchester Lighting Co. v. Westchester County Small Estates Corp., 278 N.Y. 175, 15 N.E.2d 567 (1938).

269. Slattery v. Marra Bros., 186 F.2d 134 (2d Cir. 1951). 
the right of the other to indemnity must be found in rights and liabilities arising out of some other legal transaction between the two. 270 Note that, as to the two hurdles, Judge Hand does not concern himself with the first. He assumes for the sake of argument that the third-party plaintiff could overcome it in New Jersey, since in any case the second hurdle, the exclusiveness bar, is insurmountable. In some of the cases, the first issue-whether there is any implied obligation of indemnity at all-is treated at more length. The results vary, but the final outcome is usually the same: the action fails. For this reason, there is little occasion for an extended discussion of the extent to which different states accept the fiction of an implied agreement by one wrongdoer to reimburse a lesser wrongdoer when the latter is forced to pay the damages. ${ }^{271}$

\section{B. Relation between Noncontractual Indemnity, Contractual Indemnity, and Contribution.}

In General Electric Co. v. Cuban American Nickel Co. ${ }^{272}$ for example, Judge Wisdom examines with great thoroughness the state of Louisiana law on this point and concludes that in that jurisdiction the distinction is between, not active and passive negligence, but actual and constructive fault. But in either case, the action would be barred, since its origin lies in the breach of a duty owed by the employer to the employee. In other words, the same kind of "common liability" which is a condition precedent to recovery of contribution by one tortfeasor against another is also a condition precedent to recovery of indemnity by a secondary from a primary wrongdoer. And there can be no such common liability, because the employer's liability to the employee, which is a special and exclusive liability under the compensation act, cannot be a liability in common with the third party's liability.

Indeed, this class of cases is not so much different from the ordinary contribution cases as might at first appear. The fiction of implied promise can be applied just as readily to ordinary contribution between tortfeasors as to indemnity between primary and secondary tortfeasors, and has indeed been used in some jurisdictions as the theoretical justification for contribution. While this theory is unnecessary to account for

270. Id. at 139 .

271. For a discussion of this fiction, see Woodward, The Law of Quasi-Contracts $\$ 259$, (1913).

The Supreme Court of the United States has held that, when one person's guilt consists of creating a dangerous condition, and the other's consists only of failing to discover it, the former's negligence is primary and subjects him to this indemnity obligation. Union Stockyards Co. v. Chicago, B. \& O. Ry., 196 U.S. 217, 222 (1905).

272. 396 F.2d 89 (5th Cir. 1968) (applying Louisiana law). 
contribution, ${ }^{273}$ it would, in jurisdictions where it is accepted, support an argument that contribution can be demanded of the employer by the third party with just as much reason as indemnity, if both are based on the fiction of a separate obligation running from the employer to the third party.

The attempt to assert noncontractual indemnity often occurs in cases in which the relation between the employer and third party is indeed contractual at base. Here its role is that of "second string to the bow" of the third-party plaintiff. In such cases, however, it has never added anything to the third party's case. If he has failed to establish a Ryan-type indemnity running with the contract, it is not surprising that he has fared no better in trying to extract a noncontractual indemnity from the same facts. On the other hand, in one or two cases courts have begun by finding that the facts in the case would support a common-law right of indemnity on the active-passive negligence theory, but then, finding that route blocked by the exclusive-remedy clause, have gone on to say that the same facts would also support an implied contractual warranty of the Ryan type not barred by the act. ${ }^{274}$

In some cases there is no contract whatsoever between the parties. Thus, in United Air Lines, Inc. y. Weiner ${ }^{275}$ there was simply an air collision and in City of Abilene v. Jones, ${ }^{276}$ an automobile-tractor collision. There may also be a contractual relation of sorts, but not one along which an implied obligation can travel, or at least not travel in the necessary direction. In Bertone v. Turco Products, Inc. ${ }^{277}$ the third party was the manufacturer and the employer the purchaser of a dangerous solvent. If the positions had been reversed, a separate implied duty running with the goods might have been found. But when a purchaser buys a product, does he make an implied contract with the manufacturer to use the goods in such a way as not to bring liability upon the manufacturer? This would be stretching the concept of contract out of all relation to reality. The court's approach to the matter assumed that the employer's duty to the manufacturer, if any, would have to be one based on its relative negligence, and on that basis the duty could not survive the exclusive-liability clause. ${ }^{278}$

273. Camp v. Bostwick, 20 Ohio St. 337 (1870).

274. American President Lines, Ltd. v. Marine Terminals Corp., 234 F.2d 753 (9th Cir. 1956); McDonnell Aircraft Corp. v. Hartman-Hanks-Walsh Painting Co., 323 S.W.2d 788 (Mo. 1939).

275. 335 F.2d 379 (9th Cir.), cert. dismissed, 379 U.S. 951 (1964).

276. 355 S.W.2d 597 (Tex. Civ. App. 1962).

277. 252 F.2d 726 (3d Cir. 1958) (applying New Jersey law).

278. Id. at 728-29. 
A similar attempt to make a manufacturer's warranty relationship operate in reverse was thwarted in A. O. Smith Corp. v. Associated Sales \& Bag Co. ${ }^{279}$ Here the manufacturer of an apron, bought by the employer from a supplier, was ultimately held liable for injuries to the employee when the apron caught fire. The manufacturer attempted to recover over against the employer on the ground that the employer was negligent in letting the employee use the apron. The action was held barred, since the employer could not be found jointly liable with the manufacturer in tort.

A contrary result on comparable facts was achieved by the New York Court of Appeals in Dole v. Dow Chemical Co. ${ }^{280}$ but without any discussion of the precise point here examined. In this case, the plaintiff's husband, an employee of Urban Milling Company, had died as a result of exposure to a poisonous fumigant manufactured by Dow. Plaintiff sued Dow, charging failure to give users of the fumigant sufficient warning of its danger. ${ }^{281}$ Dow in turn made claim as a third-party plaintiff against Urban, alleging negligent failure to follow precautions on the label and in the accompanying literature, use of untrained personnel for this work, and failure to air out the premises properly after fumigation. ${ }^{282}$ The court of appeals held that Dow's claim would lie, and could be tried either separately or together with the widow's case, in the discretion of the court. 283 The main innovation of the holding, and the one that has made it one of the most important tort cases in New York's history, was the abandonment of the "active-passive" negligence test in determining whether indemnification will be allowed in such cases, and the launching of a new rule that the right to indemnity "should rest on relative responsibility and may be apportioned on the facts."284 As to the issue of exclusiveness of the compensation remedy, the court merely equated this indemnity situation ${ }^{285}$ with that in Westchester Lighting Co. v. Westchester Small Estates Corp. ${ }^{286}$

The relative responsibility of the employer and the chemical company for the wrongful death of the employee would be determined only in the action by the chemical company in which the cause asserted is based on a separate legal entity of rights to be adjudicated

279. 16 Wis. $2 d 145,113$ N.W.2d 562 (1962).

280. 30 N.Y.2d 143, 282 N.E.2d 288, 331 N.Y.S.2d 382 (1972). See text accompanying notes 62-67 supra for a discussion of other aspects of the case.

281. Id. at $145-46,282$ N.E. 2 d at 290,331 N.Y.S. 2 d at $384-85$.

282. Id.

283. Jd. at 153,282 N.E.2d at 294,331 N.Y.S.2d at 391.

284. Id. at 153, 282 N.E.2d at 295,331 N.Y.S.2d at $391-92$.

285. Id. at 152,282 N.E.2d at 294,331 N.Y.S.2d at 390.

286. 278 N.Y. 175, 15 N.E.2d 567 (1938). 
from the action by the administratrix against it (Schubert v. Schubert Wagon Co., 249 N.Y. 253).

The theoretical difficulties have been resolved for this court by Westchester Lighting Co. v. Westchester County Small Estates Corp. (278 N.Y. 175, supra) which sustained the right of plaintiff, a utility which had been found negligent in an action for causing the death of defendant's employee, to sue the employer on indemnity for having directly and negligently caused the death which in turn had com- . pelled plaintiff to pay damages in an action by the employee's estate.

The difference between the causes of action and the parties pursuing them was decisive. "Plaintiff does not sue for damages on acount of' Haviland's death. Plaintiff asserts its own right of recovery for breach of an alleged independent duty or obligation owed to it by the defendant (opn. by Loughran, J., P. 179).

That is a precise description of Dow's third-party claim here. ${ }^{287}$

The court does not appear to have been troubled by the fact that the "independent duty" in Westchester was itself based on the obligation of a primary tortfeasor to indemnify a secondary tortfeasor-a distinction the court had just been at some pains to demolish. Under Dole, apparently every joint tortfeasor has a quasi-contractual obligation to reimburse every other joint tortfeasor regardless of degree of fault. Indeed, it would seem to follow that a secondary or passive tortfeasor has such a duty to indemnify a primary or active tortfeasor. In any event, the court never addressed itself to the more stubborn difficulty that such a "duty" would not be "independent," since it arises out of the injury itself, and is "on account of" the injury, even if cast in indemnity terms. The "independent duty" in Dole could not very well be held to be based on contract, although there was a contract between the parties. The contract was simply one of sale-in this instance, of a poisonous fumigant. Clearly certain independent obligations run with the sale from the manufacturer to the buyer. But it seems unlikely that the court of appeals would be prepared to hold that an independent contractual obligation runs from the buyer to the manufacturer. To do this the court would have to announce the following doctrine: "Whenever a buyer purchases an article from a manufacturer, the buyer assumes an independent contractual obligation to the manufactuer not to use the article in such a way as to bring liability on the manufactuer."

There is very little authority for this proposition, ${ }^{288}$ and there is a

287. 30 N.Y.2d at 152,282 N.E.2d at 294,331 N.Y.S.2d at 390.

288. See Harn v. Standard Eng'g Co., 416 F. Supp. 1168 (D.S.D. 1976) (applying South Dakota law); United States Fidelity \& Guar. Co. v. Kaiser Gypsum Co., 273 Or. 162, 539 P.2d 1065 (1975). 
large and growing body of authority to the contrary. ${ }^{289}$ As an Ohio court said, in a typical chemicals case:

The mere fact that a product has been sold by a vendor to a vendee does not per se make the vendee of the product primarily liable and the vendor secondarily liable, and thereby establish an implied contract indemnity running in favor of the vendor.

Pertinent to this point, the following statement is to be found in the decision of McClish $v$. Niagara Machine \& Tool Works, supra, 266 F. Supp. at page 991: ${ }^{\circ * * *}[\mathrm{~W}]$ hen the sole contractual relationship between the parties is merely that arising out of a fully executed sales contract, the warranties run from the manufacturer to the purchaser and ultimate users, and not the reverse.***'290

In summary: when the relation between the parties involves no contract or special relation capable of carrying with it an implied obligation to indemnify, the basic exclusiveness rule generally cannot be defeated by dressing the remedy itself in contractual clothes, such as indemnity, since what governs is not the delictual or contractual form of the remedy but the question: is the claim "on account of" the injury, or on account of a separate obligation running from the employer to the third party?

\section{Policy Arguments and Merits of Various Solutions}

In evaluating the rich and rapidly-changing array of solutions, actual or proposed, to this "most evenly-balanced" problem, there are at

289. Steinmetz v. Bradbury Co., 618 F.2d 21 (8th Cir. 1980) (no implied obligation under lowa law running from the purchaser of machinery to the manufacturer to idemnify the manufacturer for the purchaser's failure to instruct his employee in the safe operation of the machine; accordingly, manufacturer could not cross-claim for indemnity from the employer, who had paid compensation to the injured worker, the plaintiff in a products liability suit); Santisteven v. Dow Chem. Co., 506 F.2d 1216 (9th Cir. 1974); Bertone v. Turco Prods., Inc., 252 F.2d 726 (3d Cir. 1958); Hill Lines, Inc. v. Pittsburgh Plate Glass Co., 222 F.2d 854 (10th Cir. 1955) (applying New Mexico law); Halstead v. Norfolk \& W. Ry., 236 F. Supp. 182 (S.D. W.Va. 1964) (applying West Virginia law), affd sub nom. Norfolk \& W. Ry. v. Anderson's Black Rock, Inc., 350 F.2d 917 (4th Cir. 1965); Therrien v. Safeguard Mfg. Co., 180 Conn. 91, 429 A.2d 808 (1980), affg 35 Conn. Supp. 268, 408 A.2d 273 (1979) (employer cannot be impleaded in worker's suit against a manufacturer of safety equipment; the buyer of equipment has no duty to the seller); Cordier v. StetsonRoss, Inc., 604 P.2d 86 (Mont. 1979); Vangreen v. Interstate Mach. and Supply Co., 197 Neb. 29, 246 N.W.2d 652 (1976); Outboard Marine Corp. v. Schupbach, 93 Nev. 158, 561 P.2d 450 (1977) (approving the interpretation of the Nevada act by the federal courts in Santisteven); Arcell v. Ashland Chem. Co., 152 N.J. Super. 471, 378 A.2d 53 (1977); Ruvolo v. United States Steel Corp., 139 N.J. Super. 578, 354 A.2d 685 (1976), modifying 133 N.J. Super. 362, 336 A.2d 508 (1975); Williams v. Ashland Chem. Co., 52 Ohio App. 2d 81, 368 N.E.2d 304 (1976); Boldman v. Mt. Hood Chem. Corp., 288 Or. 121, 602 P.2d 1072 (1979); Olch v. Pacific Press \& Sheer Co., 19 Wash. App. 89, 573 P.2d 1355 (1978); A.O. Smith Corp. v. Associated Sales \& Bag Co., 16 Wis. 2d 145, 113 N.W.2d 562 (1962).

290. Williams v. Ashland Chem. Co., 52 Ohio App. 2d 81, 92, 368 N.E.2d 304, 311 (1976). 
least two quite different approaches. One depends on which party's interests are favored. The other depends on what values are favored.

\section{A. Solutions Arrayed by Interests Affected.}

The interests of three parties are inevitably affected by any choice of solurion: the employer, the third party, and the employee.

The most pro-employer solution is to adhere to the traditional rule, which is to bar any recovery-over against the employer on either contribution $^{291}$ or implied indemnity, ${ }^{292}$ while also retaining the employer's lien on the third-party recovery to the extent of compensation payments, without regard to the employer's fault. This is definitely the majority decisional rule, and has if anything been increasing in strength, with states like Connecticut, Colorado, Oregon, North Dakota, Utah, Virginia and Wisconsin being recently added to an already one-sided list. In the lively products-liability area, a similarly lopsided majority rejects the idea of a separate duty of care running upstream from buyer to manufacturer that would support an independent obligation of indemnity. ${ }^{293}$ The primary-secondary wrongdoer source of implied indemnity has also faded noticeably, the most conspicuous evidence being the disavowal of Kittleson by Iowa in Abild, ${ }^{294}$ and again by the Eighth Circuit in Hysell. ${ }^{295}$ Several statutes have also moved in this direction, or tried to. The Longshoremen's 1972 Amendments went the furthest, invalidating even express warranties as a basis for indemnity. ${ }^{296}$ The Minnesota ${ }^{297}$ and Florida ${ }^{298}$ statutes were held unconstitutional, but Florida seems to have ended with roughly the same result by judicial decision. ${ }^{299}$ Pennsylvania's amendment survived intact. ${ }^{300}$ Illinois reasserted the requirement of joint tort liability as a

291. See, e.g., Halcyon Lines v. Haenn Ship Ceiling \& Refitting Corp., 342 U.S. 282 (1952); Newport Air Park, Inc. v. United States, 419 F.2d 342 (1st Cir. 1969); Murray v. United States, 405 F.2d 1361 (D.C. Cir. 1968).

292. See, e.g., Kudelka v. American Hoist \& Derrick Co., 541 F.2d 651 (7th Cir. 1976); General Elec. Co. v. Cuban Am. Nickel Co., 396 F.2d 89 (5th Cir. 1968); Hilzer v. MacDonald, 454 P.2d 928 (Colo. 1969).

293. See notes $288-90$ supra and accompanying text.

294. Iowa Power \& Light Co. v. Abild Constr. Co., 259 Iowa 314, 324, 144 N.W.2d 303, 309 (1966).

295. 534 F.2d 775 (8th Cir. 1976).

296. See text accompanying notes $146-47$ supra.

297. Carlson v. Smogard, 298 Minn. 362, 215 N.W. $2 d 615$ (1974) (considering MinN. Stat. ANN. \& 176.061(10) (West 1960)).

298. Sunspan Eng'g \& Constr. Co. v. Spring-Lock Scaffolding Co., 310 So.2d 4 (Fla. 1975) (considering FLA. STAT. ANN. $\$ \$ 440.11,440.11(1)$ (West 1963)).

299. Hondaille Indus. v. Edwards, 374 So. 2d 490 (Fla. 1979).

300. Tsarnas v. Jones \& Laughlin Steel Corp., 488 Pa. 513, 412 A.2d 1094 (1980). 
condition precedent to contribution. ${ }^{301}$

As to pro-third-party solutions: the Illinois ${ }^{302}$ and New York ${ }^{303}$ judicial creations go the furthest of any, providing unlimited recoveryover in the form of contribution in Illinois until the 1979 amendment, and of indemnity in New York. If we included theoretical solutions, the most extreme would be the complete abolition of third-party actions, discussed later. ${ }^{304}$

Between these extremes are the types of compromise solutions that allow recovery-over limited to the amount of the employer's compensation liability. This was the compromise first essayed by the Third Circuit in Baccile, ${ }^{305}$ then by Pennsylvania ${ }^{306}$ until abolished by legislative amendment, ${ }^{307}$ and most recently by Minnesota. ${ }^{308}$ The same end result was attempted by North Carolina ${ }^{309}$ and California, ${ }^{310}$ through the device of reducing the employee's third-party recovery by the amount of compensation, a device which, in California at any rate, proved to be anything but the simple short-cut it was intended to be..$^{311}$

Up to this point, the employee's ultimate interests have not been affected. When we sort out the various approaches, actual or proposed, according to impact on the employee's rights, we again encounter an extreme spread. Most favorable to the employee is double recoverykeeping both his third-party award and his compensation-as is possible in several states, ${ }^{312}$ including Ohio and West Virginia. Then comes the normal rule, in which the employee comes out even, in the sense that he ends with roughly the full amount of the third-party damages and no more. ${ }^{313}$ Less favorable to the employee in most instances would be the "Murray credit rule," 314 in which his third-party recovery

301. See notes $68-77$ supra and accompanying text.

302. See note 68 supra.

303. See notes $280-87$ supra and accompanying text.

304. See text accompanying notes 319 and 321 infra.

305. 187 F.2d 403 (3d Cir. 1951), rev'd sub nom. on other grounds, Halcyon Lines v. Haenn Ship Ceiling \& Refitting Corp., 342 U.S. 282 (1952).

306. See note 31 supra and accompanying text.

307. See note 30 supra.

308. See note 36 supra.

309. See Hunsucker v. High Point Bending \& Chair Co., 237 N.C. 559, 75 S.E.2d 768 (1953).

310. See Witt v. Jackson, 57 Cal.2d 57, 366 P.2d 641, 17 Cal. Rptr. 369 (1961); Tate v. Superior Court, 213 Cal. App. 2d 238, 28 Cal. Rptr. 548 (1963); Pacific Indem. Co. v. California Elec. Works, 29 Cal. App. 2d 260, 84 P.2d 813 (1938); CAL. CodE CIv. Proc. $\$ \$ 875-880$ (West 1957). See also A. LARSON, WORKMEN's COMPENSATION $\$ \S 75.21-22$ (1982).

311. See A. LARSON, WORKMEN's COMPENSATION $\$ 75.22$ (1982).

312. Id. §74.11.

313. Id. $\$ 71.20$.

314. See notes 49-61 supra and accompanying text. 
would be reduced by half if the employer was negligent-a solution that has attracted no acceptance.

Another interesting attempt to grapple with the same problem is that of Professor Clifford Davis in a 1976 article. ${ }^{315}$ His proposal is that the relative percentage of fault of the employer and of the third party should first be calculated. This percentage should then be applied to the level of benefits or damages of the respective systems. ${ }^{316}$ The third-party defendant thus would be liable for no more than the damage verdict multiplied by his percentage of fault. The employer, when subrogation occurs, would be liable for the compensation benefit multiplied by his percentage of fault. If the total damages were $\$ 10,000$, the compensation liability $\$ 2,500$, and the employer and third party each $50 \%$ negligent, the third party would be liable to the employee for $\$ 5,000$; the employer's reimbursement would be reduced by $50 \%$ of $\$ 2,500$, or $\$ 1,250$; and the employee would end up with $\$ 6,250$. Professor Davis also examines some of the difficulties of and objections in the path of this solution, but concludes that this course is within the bounds of practical possibility.

Other commentators, coming at the matter from the products liability angle, remind us that the familiar rules limiting the range of immune third parties, as well as the earliest doctrines prohibiting recovery-over by third parties against employers, were not built up in products liability cases. The argument is increasingly heard that these conventional doctrines need to be reexamined in the light of the new issue of how the impact of products liability can be most equitably, practically, and efficiently handled as a part of the total loss-sharing process. Professor Jeffrey O'Connell's proposed solution is the negotiation between employers and unions of agreements under which employees waive their rights to sue certain third-party suppliers. ${ }^{317} \mathrm{He}$ deals at some length with the obvious question of why employees would ever embrace such a bargain, as well as with the many other issues of labor law, constitutional law, and the like, that such a plan would encounter. The main thrust of his argument is that so much of the product-liability dollar is consumed in expenses and fees that the worker would be better off to agree to other uses of the money, perhaps in higher compensation benefits. ${ }^{318}$

315. Davis, Third-Party Tortfeasors' Rights Where Compensation-Covered Employers are Negligent-Where do Dole and Sunspan Lead?, 4 HofSTRA L. Rev. 571 (1976).

316. Id. 580.

317. O'Connell, Bargaining for Waivers of Third-Party Tort Claims: An Answer to Product Liability Woes for Employers and their Employees and Suppliers, 1976 U. OF ILL. L. F. 435.

318. Id. 440-42. 
The most extreme proposal, from the employee's point of view, is that his third-party suits be-not negotiated away-but abolished, as urged by Professor Bernstein. ${ }^{319}$ Again, as with O'Connell's suggestion, a quid pro quo is envisioned, in the form of a fund, provided by third parties supplementing present compensation sources, to increase compensation benefits, especially for serious injuries, and also possibly to provide cost-of-living increases. The fund would be increased by contributions at rates related to the third parties' injury-causing history. Subrogation would also be abolished. The abolition of third-party actions and subrogation was also the program of the "Special Committee on Workplace Liability Reform," formed in 1977 and headed by former Senator Taft. It similarly assumed an improvement in compensation benefits, but, unlike Bernstein, did not build them directly into the plan. Curiously, the United States Chamber of Commerce opposed the plan.

\section{B. Solutions Arrayed by Values Served.}

In the world of everyday law, by contrast with the world of abstract ethics, decisions often involve the balancing of values other than pure equity-even if pure equity could be discovered. A legal system must have some element of consistency and predictability, which means that it cannot necessarily be swayed by whatever seems to be the fairest result from one moment to the next. Moreover, a legal system must be administrable, in the sense that it must be able to translate concepts of justice into decisions of actual cases involving an almost infinite variety of complications. And so, in an issue as close as the one we are dealing with, choice of a solution will ultimately depend on the relative weight given to three competing values: stability, equity, and simplicity.

Most courts have chosen the course which respects the value of stability; that is, they have adhered to several time-honored doctrines: the rule of exclusiveness of the employer's compensation liability and his right to reimbursement for his compensation outlay; the rule that contribution between joint tortfeasors requires joint tort liability; the rule that a fictional indemnity obligation will not be implied because of varying degrees of fault of tortfeasors, and that even if it were, it would still be "on account of the injury"; and the rule that a separate duty of care does not run "upstream" from a purchaser to a manufacturer of a product. A clear illustration of the deliberate honoring of the value of

319. Bernstein, Third Party Claims in Workers' Compensation: A Proposal to Do More with Less, 1977 WASH. U.L.Q. 543. 
stability may be seen in the decisions of the Supreme Court of New Jersey in Schweizer v. Elox Division of Colt Industries, ${ }^{320}$ as it refused to emulate the North Carolina-California approach, and the Superior Court of New Jersey in Ruvolo v. U.S. Steel Corp. ${ }^{321}$ as it similarly refused to emulate the New York Dole solution. The Supreme Court of New Jersey observed in Schweizer that it would be inappropriate at this late date to make drastic judicial changes in a "carefully articulated scheme of adjustment"322 of the relative rights of all the parties that had stood for sixty years without legislative alteration. ${ }^{323}$

When courts have decided to elevate fairness above all other considerations, including stability, the result has usually been to proportion the ultimate liability of employer and third party to their relative fault, as in New York ${ }^{324}$ and, until 1979, in Illinois. ${ }^{325}$ Appealing as this is at first blush, it is subject to question in at least three respectsleaving aside the damage done to the concept of stare decisis, which the courts in these instances plainly felt was outweighed by the injustice being perpetuated. The first observation is that the New York-Illinois approach gives no weight to the factor of the employer's traditional immunity to liability beyond his compensation obligation. In other words, fairness is appraised as if between two equal strangers, ignoring the fact that one, the employer, has already made concessions and assumed liabilities to the employee, for which his immunity was the quid pro quo. The Minnesota formula at least recognizes this factor and attempts to do something about it, by placing an absolute ceiling on the employer's liability in the amount of his compensation liability. ${ }^{326}$ It is thus possible to say that the employer, in the end, pays out no more than he expected to under the compensation act. The second comment is that fairness, in this context, is even more elusive than usual, because it involves a complete mix of different kinds of fault-some real moral fault, some merely fictitious, vicarious or technical. The employer's fault is usually not personal but vicarious; the third party's fault is often virtually absolute, as in unseaworthiness, products liability, automobile owner's liability, and the like. It is no wonder that a strange kind of balancing of fault often results, when the fault being balanced is nofault on both sides. The third criticism is that the price of equity will inevitably be the sacrifice of the third value-simplicity. Litigation will

320. 70 N.J. 280, 286, 359 A.2d 857,860 (1976).

321. 139 N.J. Super. 578, 587, 354 A.2d 685, 690 (1976).

322. 70 N.J. at $286-87,359$ A.2d at $860-61$.

323. Id.

324. See text accompanying notes $62-67$ supra.

325. See text accompanying notes 68-77 supra.

326. See notes 36-38 supra and accompanying text. 
be complicated. It would appear that all three parties will have to be involved in practically all cases, with percentage assessments of fault for each. The Illinois rule was too recent and short-lived to permit examples of these complications to appear, but the proliferation of post-Dole New York cases is not encouraging. 327

\section{Suggested Solution Maximizing Simplicity.}

There is a possible solution, not in effect anywhere, that would achieve maximum simplicity without, perhaps, too shocking a departure from equity. It is a sort of adaptation of the North Carolina-California approach, with some important alterations designed in part to avoid the appalling complexities that bedeviled the California courts after Witt v. Jackson ${ }^{328}$ First, reduce the employee's recovery against the third party by the amount of compensation in all cases, not just in those involving employer negligence. And, of course, the employee keeps his compensation, thus coming out whole. Note that one enormous complication has already been eliminated-that of determining the relative fault of employer and third party. Second, abolish subrogation in all cases, and of course abolish reimbursement of the employer by the employee, since the employee has not recovered the equivalent of his compensation from the third party. The great advantage here is that the employer and his carrier are simply out of the third-party picture altogether. Third, abolish all recovery-over by the third party.

There is something for everybody in this wholesale compromise, and this is important both as a matter of fairness and as a matter of constitutionality. The employee comes out with full damages, with less complications and delays, and without the possible prejudice to his interests arising from the presence of the employer in the litigation. The employer, of course, loses some opportunities for reimbursement from the third party, but in discussions with representative carriers, the writer has been struck by how relatively little importance they attach to this factor. By the same token, in jurisdictions in which some kind of recovery-over by the third party against the employer is possible, the employer would be relieved of any such possible liability. The third party in turn, would have his liability reduced below what it is now in most jurisdictions, and in all jurisdictions in cases in which the employer was not at fault. In short, there would be only one lawsuit and

327. See A. LARSON, WORKMEN's COMPENSATION $\$ 76.84$ n. 95 (1982).

328. 57 Cal. 2d 57, 366 P.2d 641, 17 Cal. Rptr. 369 (1961). See A. Larson, Workmen's COMPENSATION $\S 75.22$ (1982). 
only one issue: was the third party at fault? The problem that caused the most difficulty in California is avoided, since it is not necessary to try the issue of the employer's negligence in the employee's suit against the third party-or at any other time. ${ }^{329}$

We thus end, not on a confident note of "this is the optimum solution," but with several choices depending on the values to be served. At least one unqualified caution will be ventured: the solution should be based on what is good for compensation law. If products liability law has got out of hand, the necessary corrections should be made within the boundaries of products liability law; they should not be made by distorting long-standing compensation principles completely out of shape.

Finally, in choosing between the values identified, it is worthwhile to recall that one of the most important values stressed by the early founders of workers' compensation was getting rid of the uncertainties and complications of common-law litigation and substituting simple, near-automatic remedies. This ideal, as it turned out, was not to be realized, but at least it can be said that any step in the direction of simplicity is a step toward one of the oldest and finest traditions of workers' compensation. 